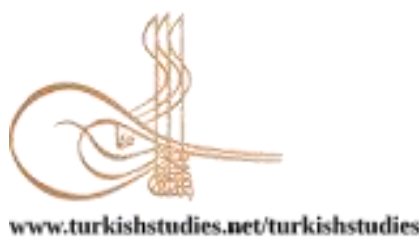

Turkish Studies

\title{
Arazi Örtüsü Çatışma Alanlarına Dayalı LUCIS Arazi Kullanım Modeli: Gölbaşı İlçesi Örneği
}

\author{
LUCIS Land Use Model Based on Land Cover Conflict Areas: The Case of Gölbaşı District
}

\author{
Kerime Karabacak* - Rüya Bayar**
}

\begin{abstract}
This study aimed to examine the Geographical Information Systems-based LUCIS (Land Use Conflict Identification Strategy) model and to apply it in Gölbaşı district of Ankara. In line with this purpose, targets and objectives were determined primarily to determine the suitability of the agriculture, conversation and settlement areas; data inventory suitable for these purposes has been made and conformity analyzes have been carried out based on the criteria in the original model. Each area was evaluated in sub-categories for suitability analysis; the criteria obtained were subjected to suitability analyses in a hierarchical order, and suitability maps were produced for three main areas through the induction method. Then, these three area were classified as low, medium and high and were overlaid, and the areas that overlap on pixel basis were determined. Based on the combination of codes in the table of characteristics, low, medium and high conflict areas were re-created. While non-conflict areas preserved their former characteristics, the next preference in conflict areas was determined according to the dominant feature. Thus, the aim was achieved by deciding which pixel will be allocated to which main area in the next period. As a result, it has been determined that $66 \%$ of Gölbaş1 district collides between land cover classes and this conflict is rather moderate. In the assignments arising due to the conflict areas, it was observed that the residential areas in the northern part of the district will expand and the other areas will remain almost the same. When the result obtained is evaluated with the existing land cover and development, LUCIS model gave a successful result for Gölbaşı district.
\end{abstract}

Structured Abstract: This study aimed to examine the Geographical Information Systems-based LUCIS (Land Use Conflict Identification Strategy) model and to apply it in Gölbaşı district of Ankara. With the LUCIS model, suitability is determined for three main areas which are Special Environmental Protection Areas, Agricultural Areas, and Settlements. For this reason, each area was evaluated in sub-categories for suitability analysis; the criteria obtained were subjected to suitability analyses in a hierarchical order, and suitability maps were produced for three main areas through the induction method. Then, these three aims were classified as low, medium and high and were overlaid, and the areas that overlay on pixel basis were determined. Based on the combination of codes in the table of characteristics, low, medium and high conflict areas were re-created. While non-conflict areas preserved their former characteristics, the next preference in conflict areas was

\footnotetext{
* Dr. Öğr. Üyesi, Ankara Üniversitesi, Dil ve Tarih-Coğrafya Fakültesi, Coğrafya Bölümü, Asst.. Prof., Ankara University, Faculty of Languages History and Geography, Department of Geography ORCID 0000-0002-9679-855X

kkarabacak@ankara.edu.tr

** Doç. Dr., Ankara Üniversitesi, Dil ve Tarih-Coğrafya Fakültesi, Coğrafya Bölümü,

Assoc.Prof., Ankara University, Faculty of Languages History and Geography, Department of Geography, ORCID 0000-0003-3115-3707

rbayar@ankara.edu.tr

Cite as/ Atıf: Karabacak, K. \& Bayar, R. (2021). Arazi örtüsü çatışma alanlarına dayalı LUCIS arazi kullanım modeli: Gölbașı ilçesi örneği. Turkish Studies, 16(4), 1279-1310. https://dx.doi.org/10.7827/TurkishStudies.49821

Received/Geliş: 05 March/Mart 2021

Accepted/Kabul: 25 August/Ağustos 2021
} 
determined according to the dominant feature. Thus, the aim was achieved by deciding which pixel will be allocated to which main area in the next period.

Gölbaş1, one of the metropolitan districts of Ankara, was chosen as the application area. The area of the district, where 140.649 people lived in 2020, is $1.529 \mathrm{~km}^{2}$. The neighboring districts are Çankaya, Yenimahalle and Sincan in the north, Bala in the east, Haymana in the west, and Kulu district of Konya in the south. The most important characteristic of the district is the presence of Mogan Lake. The lake, which is rich in biodiversity, and its immediate surroundings are an important recreation area due to the proximity of the district center to the city of Ankara. For this reason, it was declared a Special Environmental Protection Area in 1990. Agricultural areas have an important place within the land cover (77\% of the surface area). In addition, proximity to Ankara has accelerated the land cover change in the northern part of the district. New settlements have started to be established particularly on the Haymana road, in the Incek section, and partly to the east of the lake. This rapid change in land cover has caused areas of agriculture, protection and settlement to be in frequent contact. For this reason, Gölbaşı district was selected as the application area.

Within the scope of the study, in the model created for land use categories, a series of main and subaims were determined in a hierarchical structure (Table 1). First, suitability for crop production and raising livestock was investigated to determine agricultural land suitability. It was aimed to determine both physically and economically suitable areas. Secondly, it was aimed to identify areas suitable for recreation, local biodiversity and protection of water quality to determine the suitability of the protected areas. Finally, for residential area suitability, firstly, the areas of suitability were considered in three main categories as residence, business and trade, and industry. Each category included sub-aims to reveal both physical and economic suitability.

With the data collected to achieve the specified aims, three different suitability maps were produced for the areas of agriculture, protection and settlements. Then, normalization and collapse operations were performed, the codes were combined and the areas of conflict were determined (Figure 1). Depending on the dominant characteristics, new assignments were then made to the conflict codes, and how the land cover in the district should be planned was calculated (Figures 2 and 3).

Areas that are suitable for more than one land cover in the district have mostly caused moderate levels of conflict. This situation was mainly observed between the agricultural and residential areas. According to the model, the winner of this conflict was agricultural areas. High conflict areas are roughly found in the north of a line that could be drawn from the southern border of the Special Environmental Protection Area to the north. It is seen that residential areas will increase in the northern part of the district. Currently, Gölbaşı district center in the northeast is a rapidly growing urban settlement. The north of the city is in contact with the Ankara metropolitan area, and the rural areas are rapidly transforming into urban catchment areas. In the northwest, İncek, Taşpınar and Hacılar have long been an attraction area for those who want to lead a quiet life away from the noise of Ankara. The recent relocation of some school campuses and state institutions to these areas has further increased this attraction, and multi-storey modern residential areas have been started to be built in these areas where there were initially low-rise garden houses. The analysis results revealed that this trend will continue.

Mogan Lake, which has ecological importance due to the biodiversity it hosts, and the reeds around it are also among the most important recreation areas in Ankara. A slight increase in protected areas is expected with the inclusion of other wetlands and the eastern forest area in the Special Environmental Protection area here. When evaluated in general terms, the LUCIS model produced acceptable results for Gölbaşı district.

Keywords: Geography, LUCIS model, land cover planning, conflict areas, GIS

Öz: Bu çalışmanın amacı Coğrafi Bilgi Sistemleri tabanlı LUCIS (Land Use Conflict Identification Strategy) modelini inceleyerek Ankara'nın Gölbaşı ilçesi için bu modelin bir uygulamasını yapmaktır. Bu amaç doğrultusunda öncelikle tarım, koruma ve yerleşim alanlarının uygunluğunu saptamak üzere hedef ve amaçlar belirlenmiş; bu amaçlara uygun veri envanteri yapılmış ve orijinal modeldeki kriterler esas alınarak ARC GIS 10.1 yazılımı kullanılarak uygunluk analizleri gerçekleştirilmiştir. Uygunluk analizleri için her bir alan alt kategorilerde değerlendirilmiş, elde edilen kriterler hiyerarşik düzende uygunluk analizlerine tabi tutulmuş ve tümevarım yoluyla 3 temel alan için uygunluk haritaları üretilmiştir. Ardından bu üç temel alan; düşük, orta ve 
yüksek olarak sınıflandırılarak çakıştııılmış, piksel bazında örtüşen alanlar belirlenmiş ve öznitelik tablosundaki kodların birleşimine göre yine; düşük, orta ve yüksek çatışma alanları oluşturulmuştur. Çatışma olmayan alanlar eski özelliğini korurken, çatışma alanlarında bir sonraki tercih baskın özelliğe göre belirlenmiştir. Böylece izleyen dönemde hangi pikselin hangi ana alana ayrılacağına karar verilerek amaca ulaşılmıştır. Sonuç olarak Gölbaşı ilçesinin \%66'sında arazi örtüsü sınıflarının çatıştığı ve bu çatışmanın daha ziyade orta derecede olduğu tespit edilmiştir. Çatışma alanlarına bağlı olarak ortaya çıkan atamalarda ise ilçenin kuzey kesiminde yerleşim alanlarının genişleyeceği, diğer alanların ise hemen hemen aynı kalacağı görülmüştür. Elde edilen sonuç mevcut arazi örtüsü ve gelişimi ile değerlendirildiğinde LUCIS model Gölbaş1 ilçesi için başarılı bir netice vermiştir.

Anahtar Kelimeler: Coğrafya, LUCIS model, arazi örtüsü planlaması, çatı̧̧ma alanları, CBS

\section{Giriş}

Doğal ortamın insana sağladığı imkânlar çerçevesinde ortaya çıkan ve genellikle beşeri özelliklere bağlı olarak değişen arazi kullanımı, sürdürülebilirliğin sağlanması açısından en önemli konulardan birini oluşturmaktadır. Zira arazi kullanım kararlarının neden olduğu arazi kullanım değişiklikleri, doğal kaynak kaybı ve bozulmaların birincil nedenidir. Bu sebeple, ekonomik, sosyal ve ekolojik dengelerin dikkate alınarak arazinin farklı kullanım alanları için tahsis edilmesini ifade eden arazi kullanımı planlaması büyük bir öneme sahiptir. Planlama çalışmalarının ana hedefi, arazinin ve doğal kaynakların daha etkili, dengeli ve verimli bir şekilde kullanılmasını sağlayarak hem optimum arazi kullanımını hem de sürdürülebilir arazi yönetimini gerçekleştirmektir. Bu amaca uygun olarak arazi kullanımı planlaması ile öncelikle mevcut ve gelecekteki ihtiyaçlar değerlendirilerek arazinin bunları karşılamak için uygun olup olmadığı tespit edilmekte; farklı kullanımlar ve ihtiyaçlar arasındaki örtüşmeler ve uyuşmazlıklar tanımlanarak alternatif seçenekler belirlenmekte ve geçmişteki deneyimler aracılığıyla hedeflere en uygun olanları seçilmektedir (De Wrachien, 2003: 474).

Dünya üzerindeki arazi kullanımı benzerlikleri ve farklılıkları araştırmacıları arazi kullanım planlaması konusunda modeller oluşturmaya yönlendirmiştir. Coğrafi Bilgi Sistemleri ve Uzaktan Algılama tekniklerinin yaygın kullanımına bağlı olarak, planlama modelleri de gelişerek çeşitlenmiştir. Farklı tanımları olmakla birlikte model kavramı gerçek dünyanın temsili olarak özetlenebilir ki, bu tanım bilgisayar teknolojilerinin gelişmesine paralel olarak; "Gerçek dünyanın bir veya daha fazla yönünün dijital temsilini ortaya koyan ve bunları yeni bir temsil oluşturmak için dönüştüren bir bilgisayar programıdır.” (Goodchild, 2005: 1) şeklini almıştır.

Modeller girdi ve çıktılarına göre değerlendirildiğinde statik veya dinamik özellik gösterebilir. Bir modelde hem girdi hem de çıktı, zaman içinde aynı noktaya karşılık geliyorsa statik, çıtı girdiden daha sonraki bir noktayı temsil ediyorsa dinamiktir. Örneğin; uygunluk analizleri statik modelleri oluştururken, tahmin modelleri dinamik modellere karşılık gelmektedir. Tüm bu modellerde ortak unsur, ister girdi katmanlarından karmaşık göstergeler oluşturmak için, ister dinamik bir sürecin işleyişindeki zaman adımlarını temsil etmek için kullanılsın, Coğrafi Bilgi Sistemleri'nin çok aşamalı olarak çalışmasıdır (Goodchild, 2005: 1). Karmaşık ve dinamik bir yapıya sahip olan arazi kullanım değişikliklerinin modellenmesinde statik modellerden ziyade dinamik modeller daha başarılı sonuçlar vermektedir. Bu kapsamda arazi kullanımı çalışmalarında Coğrafi Bilgi Sistemleri tabanlı olarak Hücresel Otomat, Yapay Sinir Ağları, Markov Zincirleri ve Bulanık Mantık gibi dinamik modeller geliştirilmiş farklı ihtiyaçlar doğrultusunda birden fazla model entegre kullanılarak da arazi kullanımının geleceğine yönelik tahminler oluşturulabilmiş̧ir (Karabacak, 2021: 165-177; Canpolat \& Dağl1, 2021: 88). Modeller uygulanan sahanın özelliğine göre farklı avantaj veya dezavantajlar sunabilirler. $\mathrm{Bu}$ nedenle her modelin diğer modellere göre üstün özellikleri bulunabileceği gibi eksik yanları da olabilmektedir. Örneğin farklı arazi kullanımlarının dönüşüm oranlarını olasılık matrisleri aracılığıyla hesaplama ve gelecekteki eğilimi tahmin etmede 
oldukça başarılı olan Markov Zincirlerinin mekânsal boyut eksikliği önemli bir sınırlılıktır (Karabacak, 2021: 175). Doğrusal olmayan, mekânsal ve stokastik süreçleri temsil etmede çok güçlü olan Hücresel Otomatlar karmaşık yapıları modellemede en sık başvurulan yöntemlerden biri (Li \& Yeh, 2002; Karabacak, 2021) olmakla birlikte mekânsal dağılımda sadece komşuluk ilişkisine odaklanması ve arazi kullanım değişikliklerini etkileyen politik, ekonomik ve kültürel itici güçleri göz ardı etmesi (Aburas vd., 2016; Karabacak, 2021; Mustafa vd., 2017) eleştirilen özellikleridir. Birçok değişkenin kullanılmasına imkân veren, karmaşık yapıları çözmede etkin olan ve farklı türlerdeki ölçüm verilerinin kullanılabildiği Yapay Sinir Ağları ise "Kara Kutu" şeklinde bir model olması nedeniyle kullanıcıların süreci anlaması noktasında açık bilgi sağlamamaktadır (Li \& Yeh, 2002; Karabacak, 2021; Openshaw, 1998). Modellerdeki söz konusu bu sinırlıl1klar son dönemlerde modellerin entegre kullanımlarına sebep olmuştur. Ancak bu kullanımlar her ne kadar da modellerin eksikliklerinin giderilmesine katkı sağlayıp daha başarılı bir sonuç alınmasına yol açsa da her araştırma kendine özgü sonuçlar barındırmaktadır (Karabacak, 2021: 178). Bu nedenle arazi kullanımının modellenmesinde başarılı sonuçlar elde edebilmek için çalışılacak olan sahanın özelliklerine göre farkl1 modeller tercih edilmektedir.

Dinamik model özelliği gösteren LUCIS (Land Use Conflict Identification Strategy) modeli de, Coğrafi Bilgi Sistemleri tabanlı geliştirilen arazi kullanım planlaması modellerinden biri olarak literatürde yerini almıştır. Dinamik modellerin krmaşık yapıların modellenmesinde daha başarılı sonuçlara ulaşması bu çalışmada LUCIS modelin tercih edilme sebeplerinden biri olmuştur. Ayrıca, arazi kullanımı değişimini baz alan diğer modellerden farklı olarak LUCIS modelinde uygunluk analizleri temel alınarak çatışma alanları saptanmakta ve geleceğe yönelik öngörü bu alanlara bağlı olarak belirlenmektedir. Çalışma alanı olarak seçilen Gölbaşı ilçesinde birden fazla dönüşüm alternatifinin bir arada bulunduğu çatışma alanlarının varlığı, ilçenin Ankara şehrinin hemen güneyinde yer alması ve hızlı bir dönüşüm içerisine girmesi LUCIS modelin tercih edilmesinde etkili olan diğer bir faktör olmuştur. Bu nedenle bu çalışmada Gölbaşı ilçesinin arazi örtüsünü LUCIS model aracılığıyla değerlendirerek, ilçedeki çatışma alanlarını belirlemek ve bu alanlara bağlı olarak geleceğe yönelik arazi örtüsü tahminlerini yapmak amaçlanmıştır.

“Çatışma Alanı" kavramı özellikle hızlı arazi kullanım dönüşümü yaşanan alanlarda, birden fazla dönüşüm alternatifinin bir arada bulunmasına karşılık gelmektedir. Uyuşmazlık alanı olarak da (Taşdemir \& Kaya, 2015; Nayim, 2014) kullanılan bu kavram, arazi kullanımı diskordans alanlarından ziyade örtüşme alanlarını ifade etmesi nedeniyle bu çalışmada "çatışma alanı" olarak kullanılmıştır. Bu modelin ortaya çıkışından sonra çatışma alanlarının tespitine bağlı olarak planlama çalışmalarında kullanılması da yaygınlaşmıştır. Örneğin, Zou ve arkadaşları (2021) Çin'in güneydoğusunda yer alan Nan'an şehri için ekolojik-üretim-yaşam perspektifine dayanarak, potansiyel arazi kullanım fonksiyonu çatışmalarını mekânsal olarak tanımlamışlar ve bu çatışma alanlarına bağlı olarak bir yoğunluk modeli geliştirmişlerdir. Iojă ve arkadaşları (2014) Bükreş metropolitan alanında hemen hemen LUCIS modeline benzer bir yöntemle çatışma alanlarını belirlemiş; şehir gelişme göstergelerini ve mekânsal göstergeleri dikkate alarak analitik hiyerarşi yöntemiyle çatışma alanlarını planlarına dâhil etmişlerdir. Görmüş ve arkadaşları (2017) ise farklı bir değerlendirme ile önce 1987-2013 yılları arazi örtüsü değişimlerinden şehirsel büyüme eğilimini ortaya koymuşlar ardından LUCIS model ile çatışma alanlarını belirleyerek geleceğe yönelik öngörülerde bulunmuşlardır. LUCIS model sadece elde ettiği genel sonuçla değil hiyerarşik yapısı nedeniyle uygunluk analizlerinde de yaygın olarak kullanılmıştır. Örneğin, Nayim (2014), konut alanları için fiziksel uygunluğun; Taşdemir ve Kaya (2015) yerleşim alanı için uygunluğun; yine Taşdemir (2015) tarım alanları için uyguluğun tespit edilmesinde LUCIS modelini kullanmıştır. Modelin ana mimarları ise Carr ve Zwick'tir (Carr \& Zwick, 2007). Ayrica, Nayim (2011) ve Taşdemir (2017) LUCIS modeli baz alarak hazırladıkları doktora tezlerinde modelin ayrıntılı ve uygulanabilir açıklamalarını sunmuşlardır. 
Florida Üniversitesinde geliştirilen LUCIS modeli (Nayim, 2011; Taşdemir, 2017), Carr ve Zwick tarafindan uygulamalı olarak 'Smart Land-Use Analysis: The LUCIS Model' adlı kitaplarında tüm detaylarıyla açıklanmış ve uygulamaları CD ortamında araştırmacılara sunulmuştur (Carr \& Zwick, 2007). Aslında bu modelin kavramsal temelini, Odum'un "Ekosistem Geliştirme Stratejisi" çalışması oluşturmuştur (Odum, 1969; Carr \& Zwick, 2007) ve modelde kullanılan uygunluk analizleri Ian McHarg'ın "Doğa ile Tasarım" adlı eserinde ekolojik planlama yaklaşımı çerçevesinde geliştirdiği "map overlay" tekniği ile hazırlanmıştır (Görmüş vd., 2017; Carr \& Zwick, 2007; McHarg, 1969). Böylece, bu model ile arazi kullanım tercihlerini belirleme ve olası arazi kullanım çatışmalarını haritalama yoluyla gelecekteki arazi kullanımına karar verilmiştir.

"Land Use Conflict Identification Strategy" kelimelerinin baş harfleriyle isimlendirilen modelde geleceğe yönelik planlama, arazi kullanımı çatışma alanlarının belirlenmesi ile gerçekleştirilmektedir. Arazi kullanımı çatışması ise belirli bir arazi birimi içindeki farklı arazi kullanım kategorilerinin her biri için uygunluk düzeyinin karşılaştırılması ile tespit edilmektedir (Carr \& Zwick, 2007).

LUCIS model, alternatif alan kullanım önerilerini temel alarak geleneksel arazi kullanımı uygunluk analizlerinin zorluklarını ortadan kaldırmak amacıyla sadece üç temel alan üzerine geliştirilmiştir. Bunlar; doğal koruma alanları, tarım alanları ve yerleşim alanlarıdır. Ana hedef öncelikle bu üç temel alan için uygunluk belirlemektir. Bu nedenle uygunluk analizleri için her bir alan, alt kategorilerde değerlendirilir. Elde edilen kriterler hiyerarşik düzende uygunluk analizlerine tabi tutulur ve tümevarım yoluyla 3 temel alan için uygunluk haritaları üretilir. Elde edilen üç uygunluk haritası düşük, orta ve yüksek olarak sınıflandırılarak tarım, koruma ve yerleşim alanları için kodlanıp, çakıştırılarak piksel bazında örtüşen alanlar belirlenir. $\mathrm{Bu}$ aşamada öznitelik tablosundaki kodların birleşimine göre düşük, orta ve yüksek (üçlü) çatışma alanları oluşturulur (Şekil 1). Çatışma olmayan alanlar eski özelliğini korurken, çatışma alanlarında bir sonraki tercih baskın özelliğe göre belirlenir. Üç ana kriterin de yüksek çatışma alanında yer aldığı bir pikselin, bir sonraki dönem hangi alana dönüşeceğine ise şu şekilde karar verilmektedir:

1-Doğal koruma alanları en baskın özelliğe sahiptir. Yüksek üçlü çatışma alanlarında tercih her zaman bu alanlardan yanadır.

2- Tarım alanları ikincil baskın alandır. Doğal koruma alanları ile çakıştığında tercih edilmemekle birlikte, yerleşim alanlarıyla olan bir çatışmada tarım tercih edilir.

3- Yerleşim alanları ise tercihlerde en çekinik temel alandır. Baskın olmadığı alanlar dışında tercih edilmez.

Böylece elde edilen çatışma alanlarına bağlı olarak bir sonraki dönemde hangi pikselin hangi ana alana ayrılacağına karar verilerek sonuca ulaşılmaktadır. 


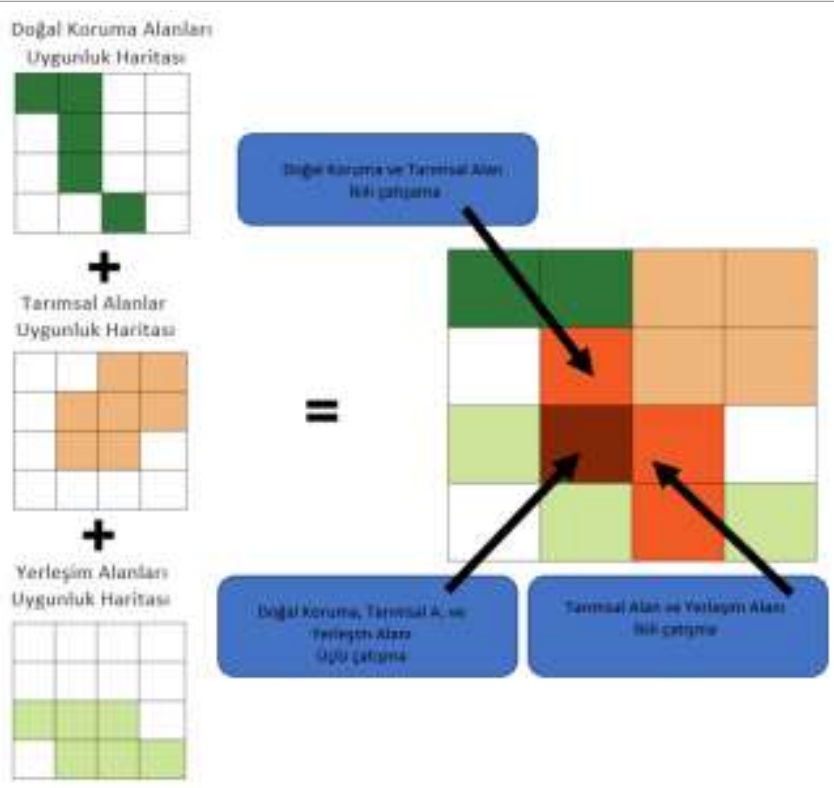

Şekil 1. Uygunluk Haritalarının Çakıştırılması ile Oluşturulan Çatışma Alanlarının Tespiti

\section{2. Çalışma Alanının Yeri ve Genel Özellikleri}

LUCIS modelinin uygulama alanı olarak Ankara'nın metropolitan ilçelerinden biri olan Gölbaşı seçilmiştir. 2020 yıll verilerine göre idari olarak 54 mahalleden oluşan ve 140.649 kişinin yaşadığı ilçenin yüzölçümü $1.529 \mathrm{~km}^{2}$ ' dir (harita üzerinden hesaplanmıştır). Çalışma alanının büyük bir bölümü İç Anadolu Bölgesi’nin, Yukarı Sakarya Bölümü’nde yer almakla birlikte, ilçenin doğusunda bir kısım arazi ise Orta Kızılırmak Bölümü'ne girmektedir. Kuzeyde Ankara'nın Çankaya, Yenimahalle ve Sincan; doğuda Bala; batıda Haymana ilçeleriyle ve güneyde Konya'nın Kulu ilçesiyle komşu durumdadır (Şekil 2).

Emles bir topoğrafyaya sahip ilçede yükselti ve eğim Mogan Gölü’nün doğu ve batısında artış göstermekle birlikte ilçenin kuzeydoğusunda yer alan Elmadağ yamaçlarında 1.553 m'den, Mogan Gölü kıyısında 950 m'lere kadar düşmektedir (Şekil 2). İlçenin en karakteristik özelliği alüvyal bir set gölü olan Mogan Gölü’nün varlığıdır. Göl ve yakın çevresi, ilçe merkezinin Ankara şehrine olan yakınlığı nedeniyle, önemli bir rekreasyon alanıdır ve biyoçeşitlilik bakımından oldukça zengindir. Bu nedenle 1990 yılında Özel Çevre Koruma Alanı içerisine dâhil edilmiştir.

İlçenin diğer bir önemli özelliği ise Ankara şehrinin güneydeki yerleşim alanları ile bağlantısını sağlayan önemli bir yol güzergâhı olan Konya Yolu'nun ilçeyi kabaca kuzey-güney doğrultusunda ikiye bölmesidir. Bu anlamda Ankara'nın güneye açılan kapısı konumundadır ve Ankara ilinin birtakım sanayi tesisleri ve önemli iletişim alanları bu yol güzergâhı üzerinde yerini almıştır.

İlçedeki genel arazi örtüsü özellikleri dikkate alındığında tarım alanlarının önemli bir yere sahip olduğu görülmektedir. Nitekim yüzölçümünün yaklaşık \%77'si tarım alanlarına ayrılmıştır. Otlak alanlarının arazi örtüsü içerisindeki payı \%11 iken diğer arazi örtüsü sınıfları \%12'lik oranı eşit paylarla oluşturmuşlardır. Ankara şehrine ulaşımın kolaylığı ve yakınlığı ilçenin kuzey kesimindeki arazi örtüsü değişimini hızlandırmış ve burayı yeni konut alanları için de cazip hale getirmiştir. Özellikle, kuzey kesimde Haymana Yolu üzerinde ve kuzeybatıda İncek kesiminde yoğunlaşan bu alanlar, son dönemlerde gölün doğu yakasında da ortaya çıkmaya başlamıştır. Arazi örtüsü üzerindeki bu hızlı değişim tarım, koruma ve yerleşim alanlarının sık sık kontakt halinde bulunması Gölbaşı ilçesinin bu çalışmada uygulama alanı olarak seçilmesinin en önemli nedenidir. 

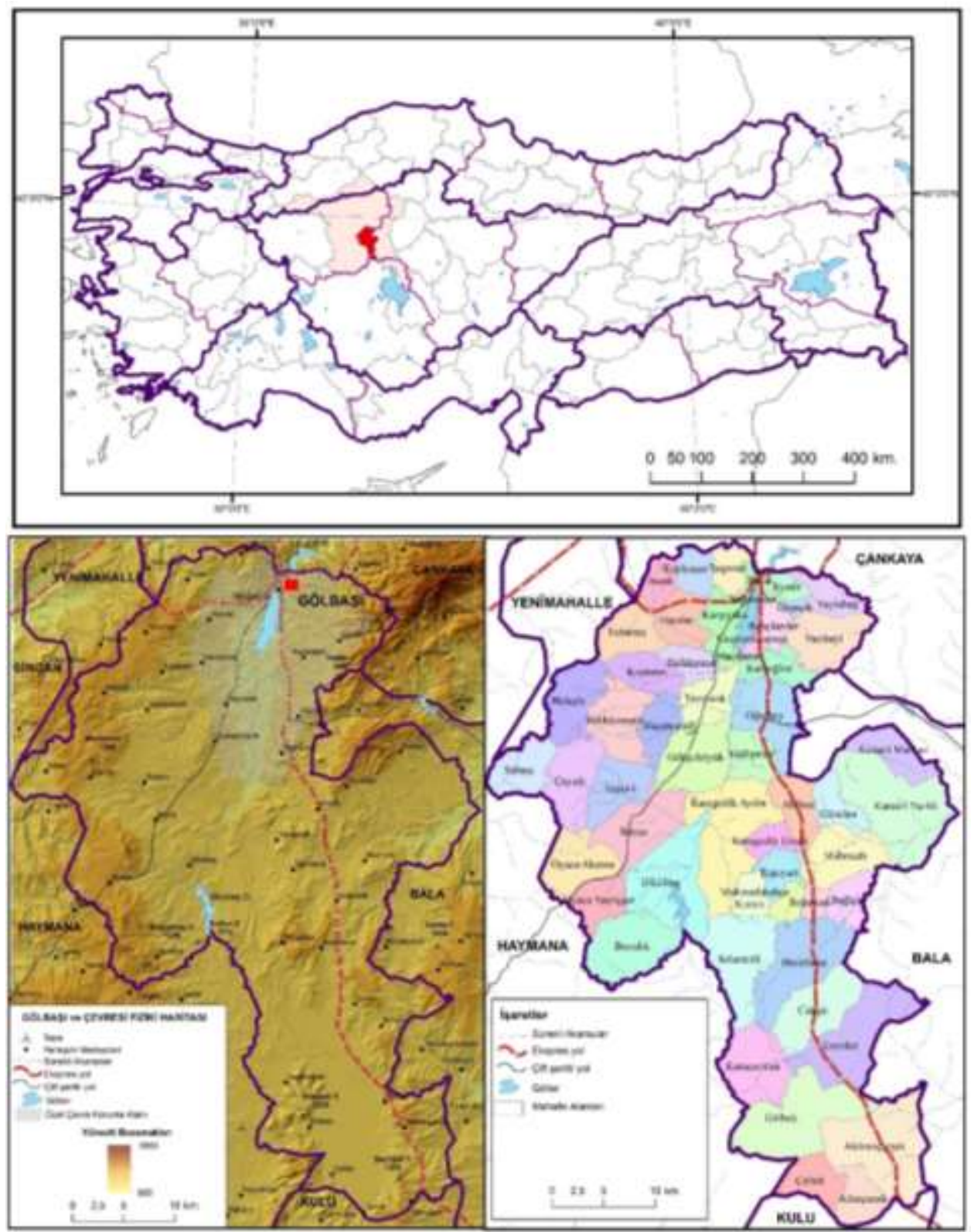

Şekil 2. Çalışma Alanının Yeri ve Sınırları

\subsection{Veri ve Yöntem}

Tarım, koruma ve yerleşim olmak üzere üç temel alanın uygunluğuna bağlı olarak çatışma alanlarını ortaya koyan ve bir sonraki adımda tercihleri belirleyen; LUCIS arazi kullanımı planlama modeli beş aşamalı olarak uygulanmaktadır (Carr \& Zwick, 2007; Nayim, 2011; Taşdemir, 2017):

1. Hedef ve amaçların belirlenmesi

2. Amaç ve hedeflere uygun veri envanteri

3. Uygunluk analizleri

4. Tercihlerin belirlenmesi

5. Çatışma alanlarının tercihlerine bağlı olarak muhtemel kullanım alanlarının atanması 


\subsubsection{Hedef ve Amaçların Belirlenmesi}

Çalışmanın birinci aşaması amaç ve hedefleri belirlemektir. Amaçlar hiyerarşik ve mantıklı bir sıra ile oluşturulur. Genel amaçlardan alt amaçlara doğru gelişen hiyerarşik yapı, alt alta birçok amacı kapsayabilir. Kriterlerin belirlenmesi için öncelikle "Üç temel alan için ayrı ayrı uygun alanların oluşması nelere bağlıdır?” sorusunun cevabı aranmalıdır. Dolayısıyla üç temel alan için bu uygunluğu oluşturacak kriterler aşağıdan yukarıya değerlendirilerek hiyerarşik bir düzende sıralanmaktadır (Şekil 3).

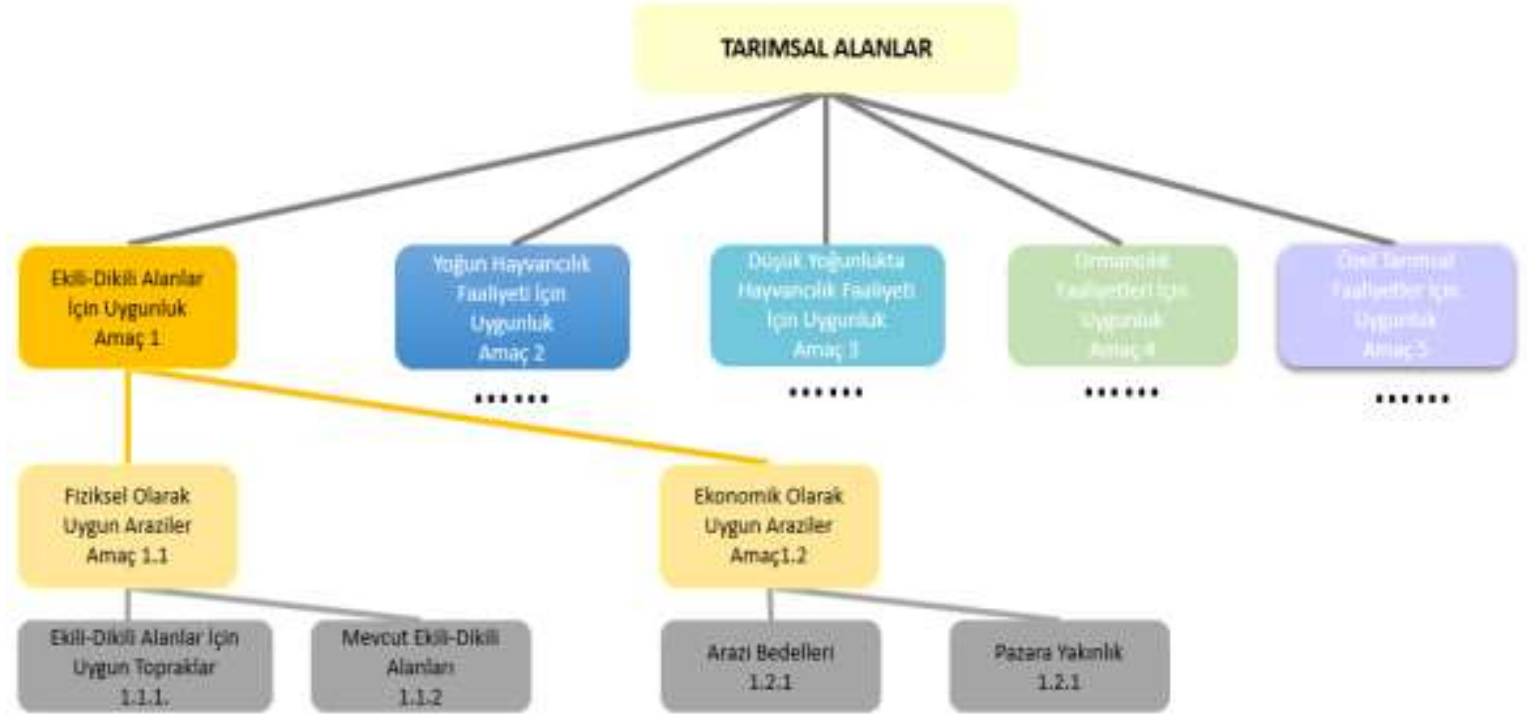

Şekil 3. LUCIS Model Uygunluk Analizi Kriter Hiyerarşisi Örneği

$\mathrm{Bu}$ nedenle tarımsal alan, koruma alanı ve yerleşim alanları için ayrı ayrı alt amaçlar, hedefler ve stratejiler belirlenmiştir. Hiç şüphesiz ana hedeflerdeki uygunlukların belirlenmesi çalışma alanına, veri yapısındaki ve erişimindeki farklılıklara bağlı olarak değişiklik gösterebilmektedir. Örneğin; tarımsal uygunluk için değerlendirme yapılırken yükseltinin kısa mesafelerde değiştiği alanlarda yükselti ve eğim koşulları önemli kriterleri oluştururken; emles topoğrafyaya sahip alanlarda bu kriterler göz ardı edilebilir. Ya da geliştirilen orijinal modeldeki bazı veri kaynaklarına erişilemeyebilir. Burada önemli olan üç ana kategori için doğru uygunluk haritalarını oluşturmaktır. Ancak dikkate alınması gereken diğer bir nokta, model hiyerarşik yapıda işleyiş̧ gösterdiği için çok fazla veriyle çalışmak, çok fazla analiz ve çakıştırmayı gerektireceği için modelin uygulanmasını da zorlaştıracaktır.

Bu çalışmada amaca yönelik olarak orijinal model amaçlarına bağlı kalınmaya çalışılmıştır. Ancak bazı verilere erişilememesi ve çalışma alanının özelliklerine bağlı olarak (ormancılık ve kerestecilik; özel tarıma uygunluk alanlarının bulunmaması gibi) kullanılamaması, alt uygunlukların belirlenmesinde farklı veri setlerinin oluşturulmasını zorunlu kılmıştır. Elde edilen veriler 1şı̆ı̆nda aşağıdaki amaçlar belirlenmiştir (Tablo 1). 
Tablo 1. Alan Kullanım Kategorileri İçin Oluşturulan Model Amaçları ve Kodları (Naim, 2011: 115-116'dan yeniden düzenlenmiştir).

\begin{tabular}{|c|c|}
\hline $\begin{array}{l}\text { 1. TARIMSAL } \\
\text { Tarım kategori }\end{array}$ & $\begin{array}{l}\text { LAN UYGUNLUĞU } \\
\text { nacı: Tarım için en uygun alanların belirlenmesi }\end{array}$ \\
\hline Kodlar & Amaçlar \\
\hline tga1 & Bitkisel üretim için uygun alanların belirlenmesi \\
\hline tgala11 & Bitkisel üretim için fiziksel açıdan uygun alanların belirlenmesi \\
\hline tga1a11aa111 & Verimlilik ve toprak kalitesi bakımından uygun alanların belirlenmesi \\
\hline tgala11aa112 & Arazi kullanım kabiliyet sınıflarına göre uygun alanların belirlenmesi \\
\hline tga1a11aa113 & Mevcut tarım alanlarının uygun olarak belirlenmesi \\
\hline tga1a12 & Bitkisel üretim için ekonomik açıdan uygun alanların belirlenmesi \\
\hline $\operatorname{tga} 2$ & Hayvancılık için uygun alanların belirlenmesi \\
\hline $\operatorname{tga} 2 \mathrm{a} 21$ & Hayvancılığa fiziksel açıdan uygun alanların belirlenmesi \\
\hline $\operatorname{tga} 2 \mathrm{a} 22$ & Hayvancılığa ekonomik açıdan uygun alanların belirlenmesi \\
\hline $\begin{array}{l}\text { 2. KORUMA A } \\
\text { Koruma katego }\end{array}$ & $\begin{array}{l}\text { ANI UYGUNLUĞU } \\
\text { amacı: Koruma için en uygun alanların belirlenmesi }\end{array}$ \\
\hline kga1 & Yerel biyoçeşitliliği korumaya uygun alanların belirlenmesi \\
\hline kgala11 & Yüksek biyoçeșitliliğe sahip alanların belirlenmesi \\
\hline kga1a11aa111 & Güncel alan kullanımlarına göre uygunlukların belirlenmesi \\
\hline kga1a12 & Nispeten düşük yol yoğunluğuna sahip alanların belirlenmesi \\
\hline kga1a13 & Mevcut korunan alanlara ve yakınlarındaki alanlara ait uygunlukların belirlenmesi \\
\hline kga1a13aa131 & Mevcut korunan alanlara ait uygunlukların belirlenmesi \\
\hline kga1a13aa132 & Mevcut korunan alanlara yakın yerlere ait uygunlukların belirlenmesi \\
\hline $\mathrm{kga} 2$ & Su kalitesini korumaya uygun alanların belirlenmesi \\
\hline kga2a21 & Yeraltı su kalitesini korumaya uygun alanların belirlenmesi \\
\hline kga2a22 & Yüzey su kalitesini korumaya uygun alanların belirlenmesi \\
\hline kga3 & Rekreasyona uygun alanların belirlenmesi \\
\hline kga3a31 & Mevcut rekreasyon alanlarının belirlenmesi \\
\hline kga3a32 & Mevcut tarihi, kültürel, arkeolojik alanların belirlenmesi \\
\hline 3. YERLEŞIM & LANI UYGUNLUĞU (Konut) \\
\hline Yerleşim kateg & amacı: Yerleşim için en uygun alanların belirlenmesi \\
\hline yga1 & Konut alanları için uygun alanların belirlenmesi \\
\hline yga1a11 & Konut alanları için fiziksel bakımdan uygun alanlar \\
\hline yga1a11aa111 & Taşkın riski bakımından uygun alanların belirlenmesi \\
\hline yga1a11aa112 & Deprem riski bakımından uygun alanların belirlenmesi \\
\hline yga1a11aa113 & Hava kalitesi bakımından uygun alanların belirlenmesi \\
\hline yga1a12 & Konut alanları için ekonomik bakımdan uygun alanların belirlenmesi \\
\hline yga1a12aa121 & Mevcut konut alanlarına yakın alanların belirlenmesi \\
\hline yga1a12aa122 & Okullara yakın alanların belirlenmesi \\
\hline yga1a12aa123 & Hastanelere yakın alanların belirlenmesi \\
\hline yga1a12aa124 & Ulaşım ağına yakın alanların belirlenmesi \\
\hline yga1a12aa125 & Parklara, tarihi mekanlara ve diğer rekreasyon alanlarına yakın yerlerin belirlenmesi \\
\hline 3. YERLEŞİM & LANI UYGUNLUĞU (İs ve Ticaret Alanları) \\
\hline Yerleşim kateg & amacı: yerleşim için en uygun alanların belirlenmesi \\
\hline yga2 & İș ve ticaret alanları için uygun alanların belirlenmesi \\
\hline yga2a21 & İș ve ticaret alanları için fiziksel bakımdan uygun alanların belirlenmesi \\
\hline yga2a21aa211 & Taşkın riski bakımından uygun alanların belirlenmesi \\
\hline yga2a21aa212 & Deprem riski bakımından uygun alanların belirlenmesi \\
\hline yga2a21aa213 & Hava kalitesi bakımından uygun alanların belirlenmesi \\
\hline yga2a22 & İş ve ticaret alanları için ekonomik bakımdan uygun alanların belirlenmesi \\
\hline yga2a22aa221 & Mevcut konut alanlarına yakın alanların belirlenmesi \\
\hline yga2a22aa222 & Ulaşım ağına yakın alanların belirlenmesi \\
\hline yga2a22aa223 & Parklara, tarihi mekanlara ve diğer rekreasyon alanlarına yakın yerlerin belirlenmesi \\
\hline
\end{tabular}




\begin{tabular}{ll}
\hline yga2a22aa224 & Mevcut iş ve ticaret alanlarına yakın yerlerin belirlenmesi \\
\hline 3. YERLEŞiM ALANI UYGUNLUĞU (Sanayi Alanları) \\
Yerleşim kategori amacı: yerleşim için en uygun alanların belirlenmesi \\
\hline yga3 & Sanayi alanları için uygun alanların belirlenmesi \\
yga3a31 & Sanayi alanları için fiziksel bakımdan uygun alanların belirlenmesi \\
yga3a31aa311 & Taşkın riski bakımından uygun alanların belirlenmesi \\
yga3a31aa312 & Deprem riski bakımından uygun alanların belirlenmesi \\
yga3a31aa313 & Yerüstü su kaynaklarına uzak alanların belirlenmesi \\
yga3a32 & Sanayi alanları için ekonomik bakımdan uygun alanların belirlenmesi \\
yga3a32aa321 & Mevcut konut alanlarına uzak alanların belirlenmesi \\
yga3a32aa322 & Mevcut sanayi alanlarına yakın yerlerin belirlenmesi \\
yga3a32aa323 & Ulaşım ağına yakın alanların belirlenmesi \\
\hline
\end{tabular}

\subsubsection{Amaç ve Hedeflere Uygun Veri Envanteri}

Arazi kullanımı analizi ve karar verme için veri kümeleri, McHarg tarafından açıklanan fiziksel, biyolojik ve ekolojik, demografik, ekonomik, siyasi, kültürel ve alt yapı verileri olmak üzere yedi geniş kategoride ele alınmaktadır (McHarg, 1969). Model kapsamında ve erişilemeyen durumlarda bu yedi kategoriye başvurularak çeşitli veriler toplanmıştır. Gerekli hallerde hem literatür aracılı̆̆ıyla hem de sel, taşkın riski ve mesafe, yoğunluk gibi analizler aracılığıyla bu temel verilerden yeni veri setleri üretilmiştir (Tablo 2).

Tablo 2. Üç Temel Alan İçin Veri Envanteri

\begin{tabular}{lll}
\hline Tarımsal uygunluk & Koruma alanları uygunluğu & Yerleşim alanı uygunluğu \\
\hline \multirow{2}{*}{ Toprak } & Sulak Alanlar & Toprak Korozyon ve Drenaj \\
Arazi Örtüsü & Koruma Alanları & Özellikleri \\
Ekili/Dikili Alanlar & Jeoloji & Taşkın Alanları \\
İdari Bölünüş & Akifer Alanları & Akarsu Yoğunluğu \\
Bölgesel Arazi Değeri & Taşkın Alanları & Akifer Alanları \\
Şehir Sınırları & Akarsu Yoğunluğu & Anayollar \\
Jeoloji & Parklar, Rekreasyon Alanları & Konut Alanları \\
Hayvancılık Alanları & Bölgesel Arazi Değeri & Sağlık Tesisleri \\
Yerleşim Alanları & Endemik Tür Yoğunluğu & Parklar, Rekreasyon Alanları \\
Meralar & Yeraltı Su Kaynakları & Deprem Riski Alanları \\
& Yol Yoğunluğu & Bölgesel Arazi Değeri \\
& & Şehir Sınırları \\
& & Sanayi Alanları \\
& & İş ve Ticaret Alanları \\
\hline
\end{tabular}

\subsubsection{Uygunluk Analizleri}

Ağırlıkları belirlenen alt kategoriler çakıştırılarak her bir alt amaç için uygunluk analizleri yapılmıştır. Örneğin; bitkisel üretim alanları için fiziki uygunluk ve ekonomik uygunluk ayrı ayrı analiz edilmiş; bu ikisi çakıştırılarak bitkisel üretim uygunluğu elde edilmiştir. Ekstansif ve entasif hayvancılık için de ayrı ayrı hem fiziki hem ekonomik uygunluk analizleri yapılmış ve bunların çakıştırılması ile uygun hayvancılık alanları belirlenmiştir. Ardından, bitkisel üretim + entansif hayvancılık + ekstansif hayvancılık uygunlukları çakıştırılarak tarımsal uygunluk genel amacına ulaşı1mıştır.

\subsubsection{Tercihlerin Belirlenmesi}

Birbirlerine göre avantajları ve dezavantajları olmakla birlikte; toplum tercihlerinin belirlenmesinde iki strateji bulunmaktadır. Bunlardan ilki uygunluk analizleri yardımıyla tek bir 
uzman gruba göre; diğeri ise toplumun geniş kitlelerini temsil eden birden fazla uzman grubun düşüncelerine göre tercih belirlemektir. Özellikle uygunluk analizleri destekli olması nedeniyle ilk stratejide Analitik Hiyerarşi ile ağırlıkların bulunması bir avantaj oluştururken; grubu oluşturan üyelerin benzer özellikleri dezavantaj olabilir. Keza ikincisinde de farklı görüşlerin bir araya gelmesi, politik açıdan uygun tercihlerin belirlenmesini sağlayabilir ancak çok grupla çalışmak zaman alıcı ve zorlu bir süreç olabilir (Carr \& Zwick, 2007). Bu çalışmada ağırlıklandırma tercihlerini belirlerken orijinal model baz alınmıştır. Atanmasi

1.3.5. Çatışma Alanlarının Tercihlerine Bağlı Olarak Muhtemel Kullanım Alanının

Mevcut yerleşim alanları, koruma statüsüne sahip araziler ve açık su alanları gibi bir sonraki dönemde hızlı değişmeyecek alanlar, bu çalışmanın analiz aşamalarında dikkate alınmıştır. Ancak, üç temel kullanım alanı uygunluk verisini sınıflandırırken maskeleme yapılarak ayrılabilir.

İkinci olarak; elde edilen uygunluk verilerinin sağlıklı karşılaştırılmasını sağlamak amacıyla min-max normalizasyonu:

$$
\mathrm{xn}=\mathrm{x}-\min (\mathrm{x}) / \max (\mathrm{x})-\min (\mathrm{x})
$$

formülü ile hesaplanarak 0 ile 1 arasında değerler üretilmiştir. Yeniden sınıflandırma ile normalleştirilmiş tercih değerleri yüksek, orta ve düşük olarak üç sınıfa indirgenmiştir. Daha sonra yeni bir sütun açılarak düşük değerler taşıyan tarım alanlarına 100, koruma alanlarına 10 ve yerleşim alanlarına 1; orta değerler taşıyan tarım alanlarına 200, koruma alanlarına 20 ve yerleşim alanlarına 2 ; yüksek değerler taşıyan tarım alanlarına 300, koruma alanlarına 30 ve yerleşim alanlarına 3 değerleri atanmıştır. "uygun tarım + uygun koruma + uygun yerleşim" çakıştırmasıyla yüzler basamağı tarımı, onlar basamağı korumayı ve birler basamağı yerleşimi ifade eden yeni kodlar oluşturulmuştur. Elde edilen kodlarda üç rakamın da aynı olması $(111,222,333)$ üç alanın da aynı pikselde uygun özellikler taşıdığını gösterir bu nedenle bu kodlarda yüksek düzeyde çatışma vardır. Kodlardaki iki rakam benzerliği (üçüncü küu̧ük olmak koşuluyla) ise orta düzeyde çatışmayı ifade etmektedir. Eğer kodu oluşturan rakamların her biri farklı ise baskın bir tercihin ortaya çıkması nedeniyle çatışma yoktur olarak kabul edilmiştir. Oluşturulan bu yeni değerlerle önce arazi kullanımı çatışma alanı haritası oluşturulmuş ardından baskın özelliklere göre belirlenen tercihlerle atamalar yapılarak planlama modeli tamamlanmıştır.

\section{Bulgular}

\subsection{Tarımsal Alan Uygunluğunun Belirlenmesi}

LUCIS modelinde tarımsal uygunluktan kasıt aslında hammadde alanları için uygunluğa karşıllk gelmektedir. Bu nedenle modelin orijinalinde, tarımsal uygunluk belirlenirken, ekili alanlar; entansif hayvancılık; ekstansif hayvancılık; ormancılık/kerestecilik; su ürünleri yetiştiriciliği, fidanlıklar ve meyve bahçeleri gibi özel tarıma uygunluk olmak üzere 5 amaca yönelik ayrı ayrı hem fiziki uygunluklar hem de ekonomik uygunluklar belirlenmiş ve bunlar çakıştırılarak ana amaç olan tarımsal uygunluğa ulaşılmıştır. Çalışma alanında 4. ve 5. amaca yönelik faaliyetler bulunmadığı için Gölbaşı ilçesi tarımsal uygunluğunun belirlenmesinde ilk 3 amaç dikkate alınmış, oldukça sınırlı olan dikili alanlar ise bitkisel üretim alanı başlığında ekili alanlarla birleştirilerek değerlendirilmiştir. Erişilebilen veri doğrultusunda kriterler orijinal model esas alınarak değerlendirilmiştir.

\subsubsection{Bitkisel Üretim Alanları İçin Uygunluk}

Bitkisel üretim alanları için fiziki uygunluk; CORINE arazi örtüsü 2018 verisi içerisinden mevcut tarım alanları ve toprak verisinde bulunan arazi kullanım kabiliyet sınıfları içerisinden işlemeli tarım için uygun olan ilk dört sınıf arazi dikkate alınarak belirlenmiş ve 
$($ Con("recarzklnm" == 9,9,("recakk"))) koşullu ifadesiyle; yani mevcut tarım alanları korunarak çakıştırılmıştır.

Ekonomik Uygunluk için; Gölbaşı Belediyesi’nin online belediye hizmetleri kapsamında kullanıcıya sunduğu arsa rayiç bedellerinin mahalle bazında ortalaması alınarak arazi bedelleri tespit edilmiştir. Arazi bedellerinin uygunluğu ve kentsel alanlara öklit mesafesi (pazar alanlarına yakınlık) dikkate alınmıș ve yine modele uygun olarak arazi bedellerine 0,75 ; pazara yakınlığa 0,25 ağırlık atanarak çakıştırılmıştır. Fiziki ve ekonomik uygunluklar 0,50'şer ağırlıkla çakıştırılarak bitkisel üretim için uygun alanlar elde edilmiştir (Şekil 4, 5 ve 6). Bitkisel üretim uygunluk sonuçlarına göre ilçe yüzölçümünün \%46's1 yüksek, \%40'1 orta derece uygunluk gösterirken, \%14'lük bir kesim bitkisel üretim için düşük ya da uygun olmayan özellikte çıkmıştır. Kabaca Özel Çevre Koruma Alanı ve yakın çevresi ilçede bitkisel üretim alanlarının çok gelişemeyeceği bir kuşak oluşturmuştur ki, bunun asıl nedeni Ankara şehrinin hemen güney çeperinde yer alan bu alanda arsa bedellerinin yüksek olmasıdır (Şekil 6).

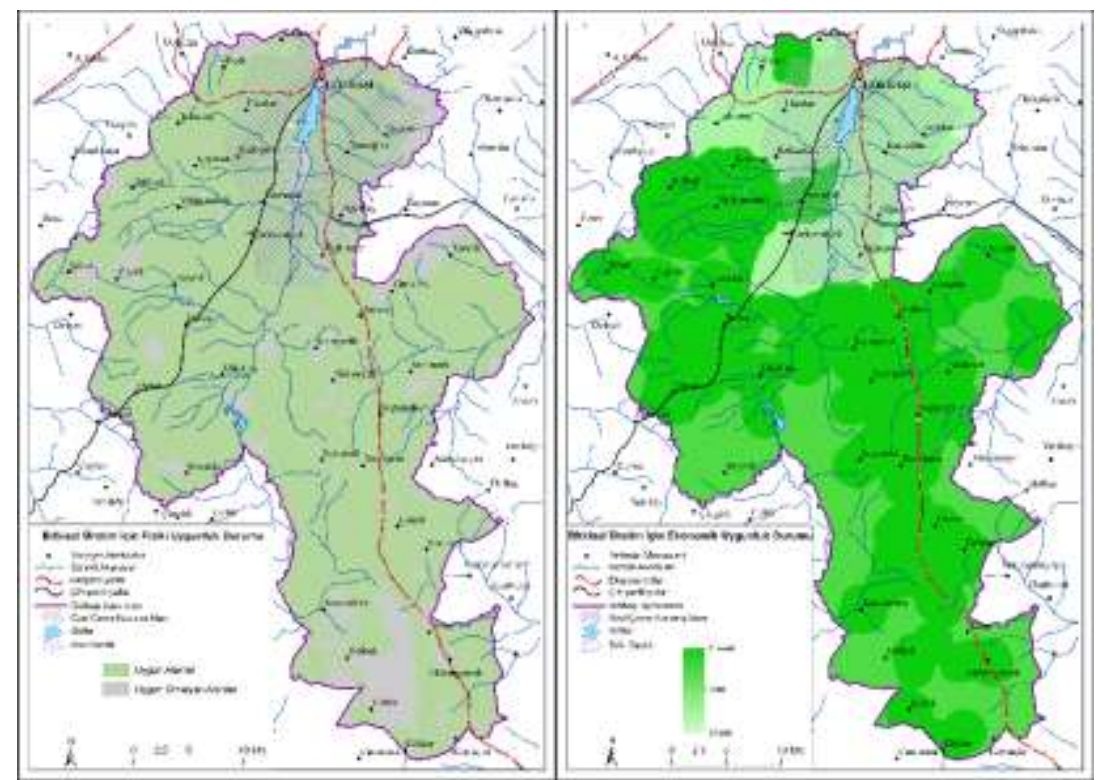

Şekil 4 ve 5. Gölbaşı İlçesinde Bitkisel Üretim İçin Fiziki ve Ekonomik Uygunluk Durumu 


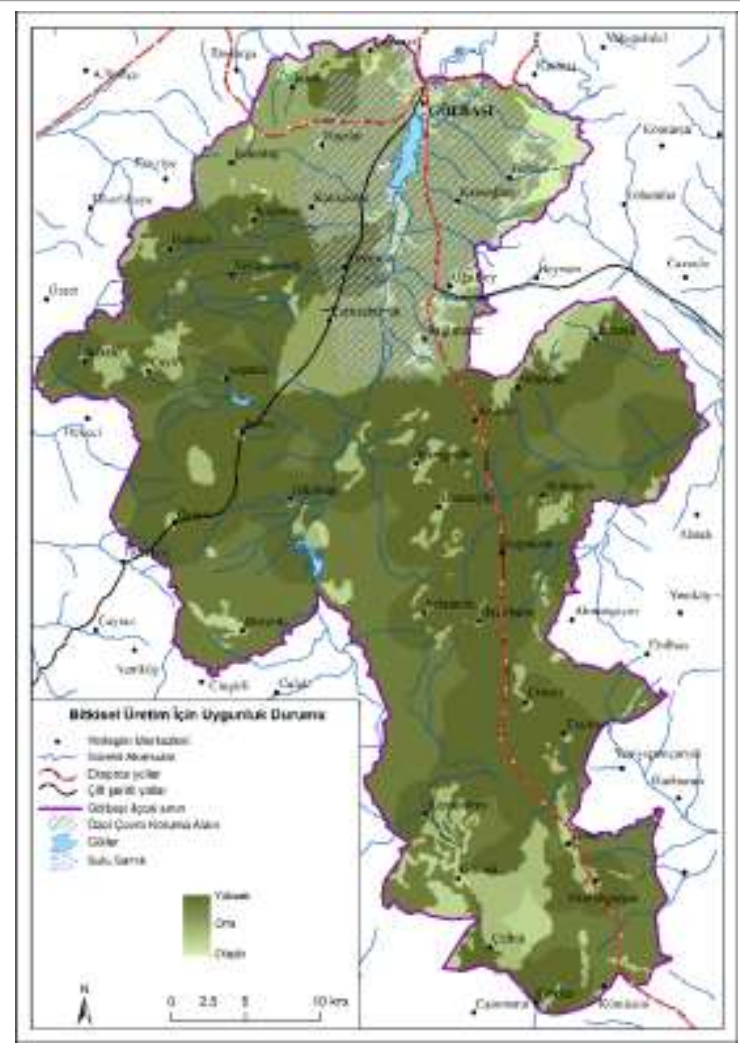

Şekil 6. Gölbaş1 İlçesinde Bitkisel Üretim İçin Uygun Alanların Dağılımı

\subsubsection{Entansif Hayvancılık İçin Uygun Alanlar}

Yüksek akifer hassasiyetine sahip alanlar, nitrojen kirliliği potansiyeline bağlı olarak mandıralar, besi çiftlikleri ve endüstriyel tavuk çiftlikleri gibi alanlar entansif hayvancılık alanları için uygun değildir (Carr \& Zwick, 2007: 10). Bu nedenle öncelikle akifer alan potansiyeli olan yerler belirlenmiştir. Bu nedenle jeoloji haritalarından alüvyon alanlar seçilmiştir. İlçede mevcut entansif hayvancılık alanları mera ve çayır alanları üzerinde ya da yakınlarında yer almaktadır. Bu nedenle arazi kullanımı verisinden otlak alanları dikkate alınmıștır. Bu iki kriter yine öncelikle otlak koşullu olarak çakıştırılmış ve entansif tarım için fiziki uygunluk alanları belirlenmiştir (Şekil 7). Ekonomik uygunluk için pazar alanı olarak öncelikle Ankara şehri, komşu ilçe merkezleri ve Gölbaşı ilçesindeki yerleşim alanlarına yakınlık dikkate alınmıştır. Bunun için öklit mesafesi hesaplanmıştır. Hayvancılık faaliyetlerinin koku nedeniyle yerleşim merkezlerinden uzak olması istenmiş bu nedenle ilçede yer alan yerleşim alanlarına uzaklık için öklit mesafesi uygulanmıştır. Son olarak arazi bedellerinin düşük olduğu alanlar tercih edilerek bu üç kriterin ağırlıklandırılarak (sırasıyla 0,20; 0,$40 ; 0,40$ olarak) çakıştırılmasıyla entansif hayvancılık için ekonomik olarak uygun alanlar belirlenmiştir (Şekil 8). 


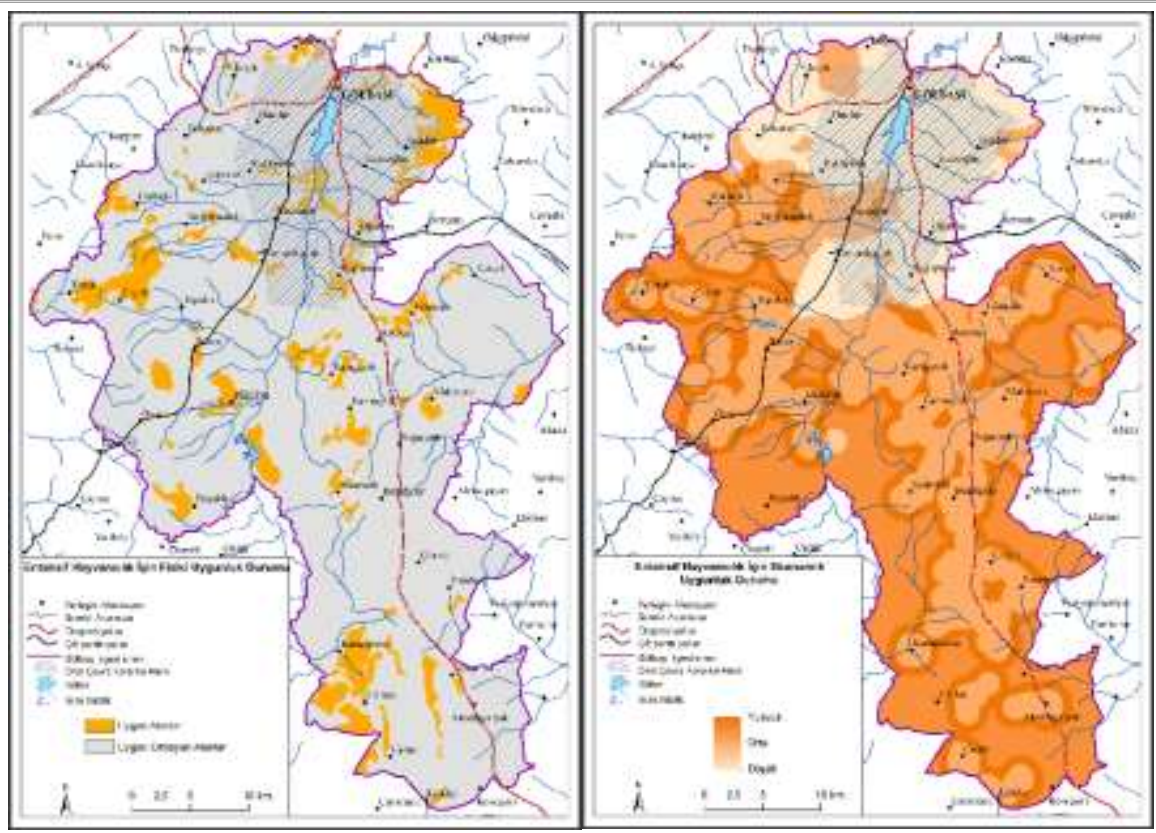

Şekil 7 ve 8. Gölbaşı İlçesinde Entansif Hayvancılık Faaliyetleri İçin Fiziki ve Ekonomik Uygunluk Durumu.

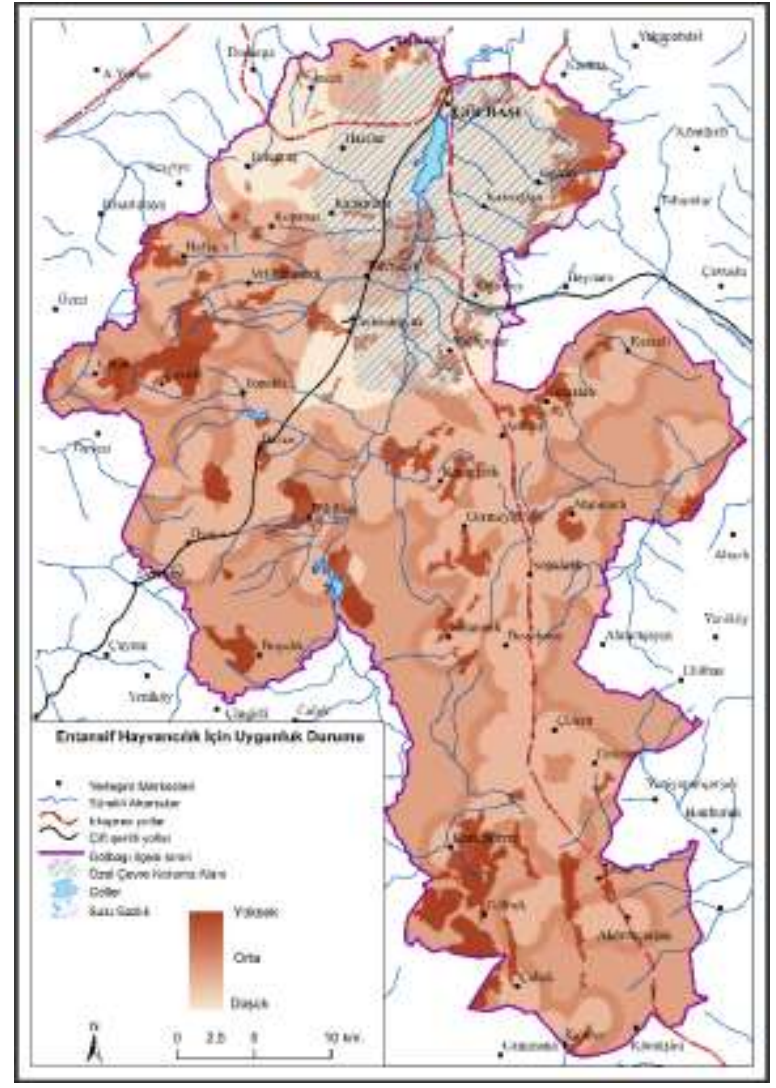

Şekil 9. Gölbaşı İlçesinde Entansif Hayvancılık İçin Uygun Alanların Dağılımı

Entansif hayvancılık için belirlenen fiziki uygunluk ve ekonomik uygunluk değerleri 0,50 ağırlıkla çakıştırılarak ilçedeki entansif hayvancılık için uygun alanlar tespit edilmiştir (Şekil 9). 
Bitkisel üretim alanlarında olduğu gibi arazi bedelleri Gölbaşı ilçesi kuzeyinde entansif hayvancılığın uygun olarak sürdürülemeyeceğini göstermektedir. Sonuç incelendiğinde, bu faaliyetin ilçe yüzölçümünün $\% 73$ 'ünde düşük, $\% 22$ 'sinde orta ve $\% 5$ 'inde yüksek uygunlukla yürütülebileceği görülmektedir.

\subsubsection{Ekstansif Hayvancılık İçin Uygun Alanlar}

Gölbaşı ilçesi kırsal alanlarında yürütülen hayvancılık faaliyetlerinin büyük bir kısmı ekstansif özellik göstermektedir. Bir bakıma hayvancılığın gelişimi çayır ve mera alanlarının varlığına bağlıdır. $\mathrm{Bu}$ nedenle modelde ekstansif tarım için fiziksel uygunluğun belirlenmesinde, toprak özelliklerinin otlak alanları için uygunluğu ile mevcut otlak alanları kriteri baz alınmıştır. Arazi kullanım kabiliyeti bakımından V., VI., VII. sınıf araziler meralar için uygun olarak değerlendirilmiş, mevcut otlak alanlarıyla koşullu olarak birleştirilmiş ve ekstansif hayvancılık için fiziki uygunluk haritası üretilmiştir (Şekil 10). Ekonomik uygunluk ise entansif hayvancılıkta olduğu gibi pazar alanlarına yakınlık ve arazi bedelleri kriterleri dikkate alınarak oluşturulmuş; arazi bedellerine 0,75 ve pazar alanlarına yakınlığa 0,25 ağırlık verilerek çakıştırılmıştır (Şekil 11). Elde edilen fiziki ve ekonomik uygunluğun 0,50 ağırlıkla birleştirilmesiyle de ekstansif hayvancılık için uygunluk durumu belirlenmiştir (Şekil 12).

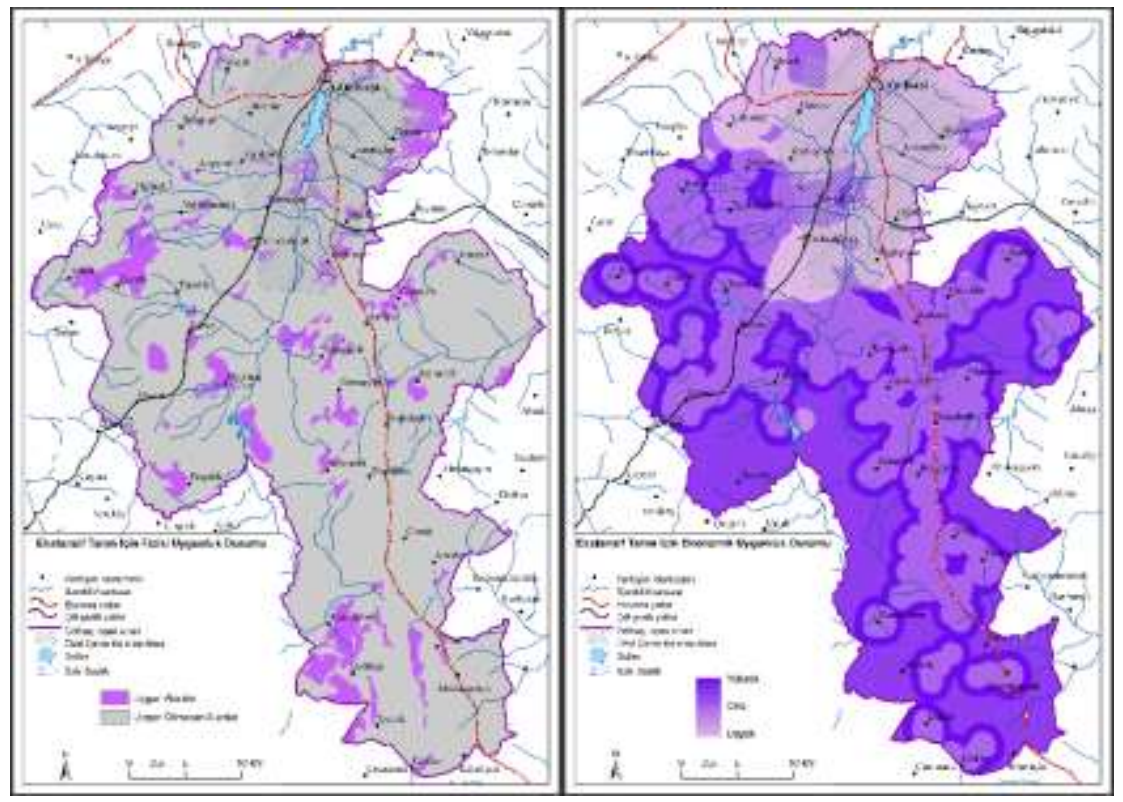

Şekil 10 ve 11. Gölbaşı İlçesinde Ekstansif Hayvancılık İçin Fiziki ve Ekonomik Uygunluk Durumu 


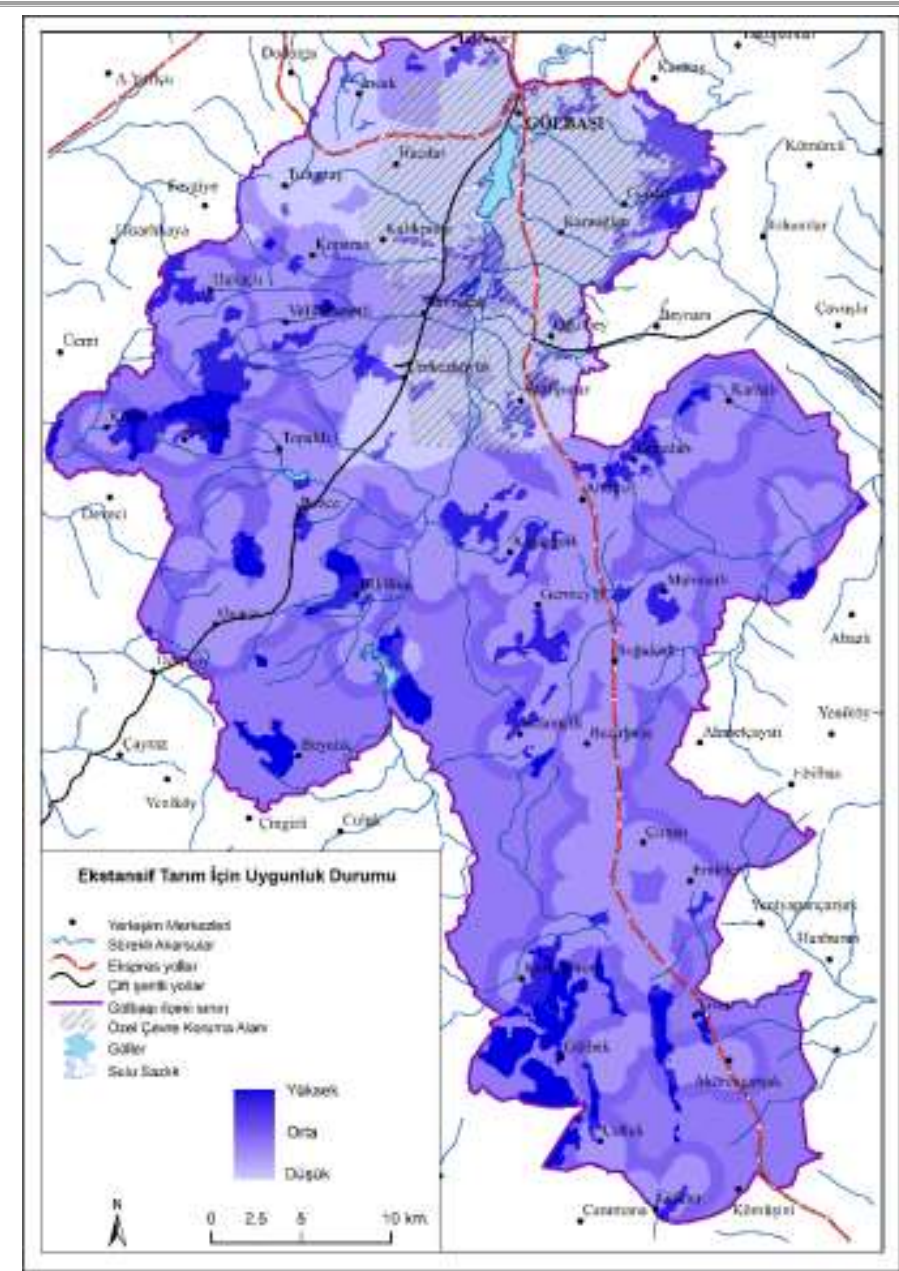

Şekil 12. Gölbaşı İlçesinde Ekstansif Hayvancılık İçin Uygun Alanların Dağılımı

İlçede yürütülen entansif hayvancılığın sınırlı olması, mevcut otlak alanları üzerinde bulunması ve Ankara şehrine yönelik üretim yapılması, hayvancılık faaliyetlerinin ister entansif ister ekstansif olsun aynı alanlar üzerinde dağılım göstermesiyle sonuçlanmıştır (Şekil 9 ve 12).

Gölbaşı ilçesinde tarımsal faaliyetler için uygunluğun belirlenmesi amacıyla bitkisel üretim uygunluğu, entansif hayvanc1lık uygunluğu ve ekstansif hayvancilık uygunluğu haritaları çakıştırılmıştır. Elde edilen bu genel amaç verisine bakıldı̆̆ında; Gölbaşı ilçe merkezini oluşturan mahalleler ve Ankara'nın yeni gelişim alanlarını barındıran kuzey mahalleler dışında ilçe geneli tarımsal faaliyetler için orta düzeyde bir uygunluk göstermektedir. Nitekim Gölbaşı ilçesinde orta düzeyde tarımsal uygunluk alanları yüzölçümünün \%96'sına karşılık gelmektedir. Düşük düzeyde uygunluk ilçenin \%3'ünde ve yüksek düzeyde uygunluk ise \%1'inde görülmektedir. Karacaali Yazlık, Gölbek, Bezirhane, Karacaviran, Selametli, Çayırlı, Topraklı, Karagedik Ercan, Subaşı ve Oyaca, alanları içerisinde en yüksek uygunluğa sahip tarım alanlarını barındıran mahalleler olmuşlardır. 


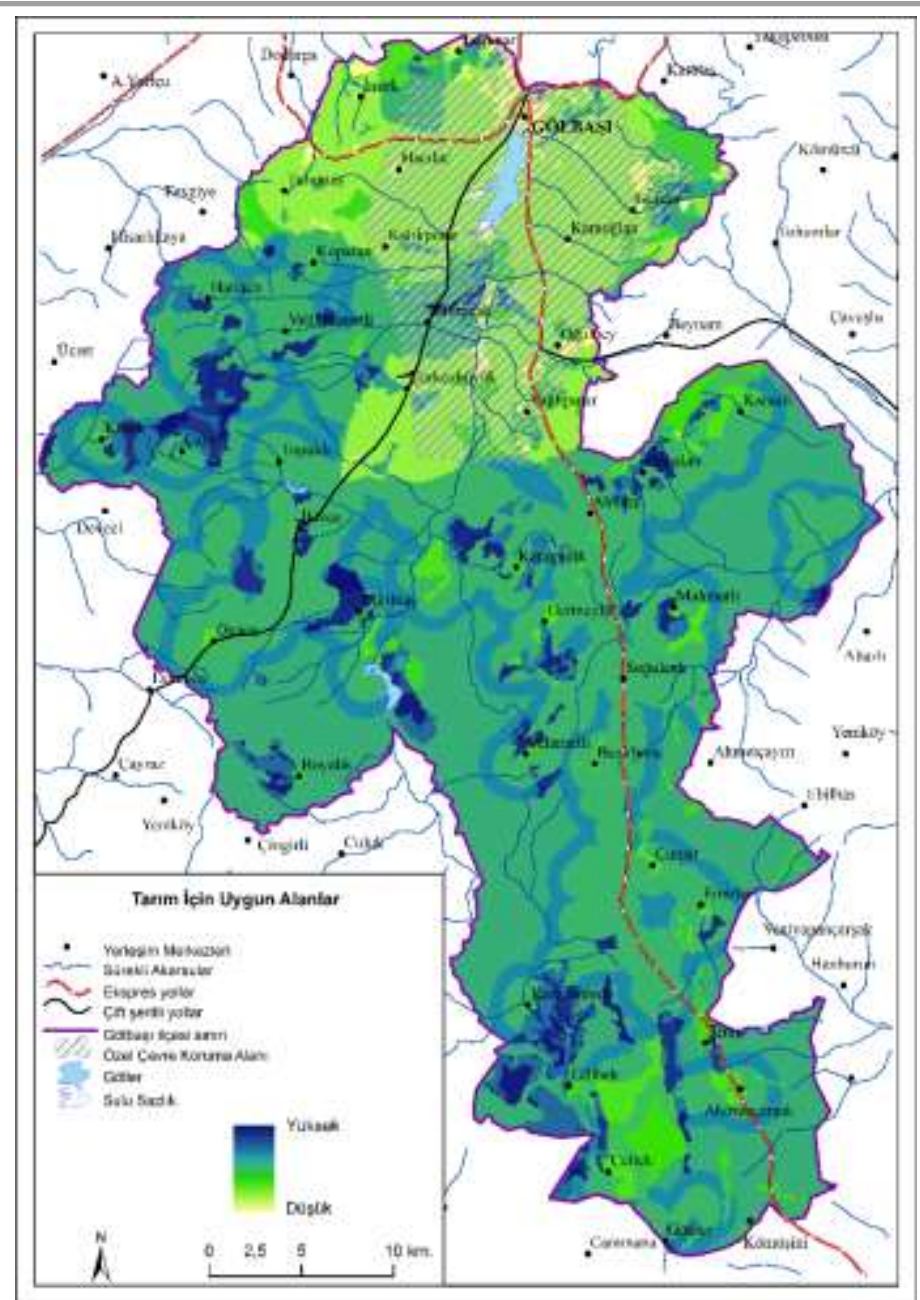

Şekil 13. Gölbaşı İlçesinde Tarımsal Faaliyetler İçin Uygun Alanların Dağılımı

\subsection{Koruma Alanları Uygunluğunun Belirlenmesi}

LUCIS modelde koruma alanlarının uygunluğunu belirlemek üzere 6 ana amaç tespit edilmiş ve bunlara ulaşmak için pek çok kriter geliştirilmiştir. Bu altı ana amaç: yerli biyoçeşitlilik, su kalitesi, ekolojik süreçler, rekreasyon, boyut ve bağl1lık ve arazi değerleridir. Ancak, bu ana amaçlara erişmek için değerlendirilen verilerin büyük bir kısmı Gölbaşı için temin edilememiştir. Bunun yerine alternatifler geliştirilerek bir koruma uygunluğu elde edilmiş, bunda da mümkün olduğunca ana amaçlara bağlı kalınmaya çalışılmıştır.

Yerli biyoçeşitliliğin yoğun olduğu alanları tespit etmek üzere mevcut sulak alanlar, mevcut koruma alanları, düşük yol yoğunluğu ve Gölbaşı ilçesi ve çevresi için hesaplanan endemik tür yoğunluğu dikkate alınmıştır. Bu verilerin çakıştırılmasıyla yerli biyoçeşitliliğin korunması için uygunluk belirlenmiştir. Bu uygun alan, Özel Çevre Koruma Alanı ve mevcut sulak alanlarla bire bir örtüşmüştür (Şekil 14).

İlçede dağılış gösteren floranın büyük çoğunluğu İran-Turan Fitocoğrafik Bölgesi'ndendir. 1990 yılında Özel Çevre Koruma Bölgesi ilan edilen alanda (Resmi Gazete, 21.11.1990) 80 familyadan 494 bitki taksonu tespit edilmiştir (Çevre ve Şehircilik Bakanlığı, 2019: 60). Türkiye'nin önemli kuş alanlarından olan Mogan Gölü ve çevresindeki sulak alanlarda 277 farklı kuş türü tespit 
edilmiştir. Özel Çevre Koruma Bölgesi ayrıca pek çok sucul ve karasal hayvan türüne de ev sahipliği yapmaktadır. Bu nedenle ilçenin biyoçeşitliliğini açıklayan önemli bir alandır.

Yeraltı suyunun korunma uygunluğunu belirlemek için akifer hassasiyetinin yüksek, su kaynaklarının yoğun olduğu alanlar çakıştırılarak korunması gereken yeraltı suyu kaynakları belirlenmiştir. Diğer korunması gereken alanlar veri yetersizliği nedeniyle tek bir grupta toplanmıştır. Yüzey suyu kalitesini korumak için akarsulara yakın yerlere tampon bitkiler önerilebilir bu nedenle akarsuya yakınlık hesaplanmıştır. Taşkınları belirlemek için akarsulara dikey mesafe hesaplanarak $10 \mathrm{~m}$ altında kalan alanlar belirlenmiştir. Yangın riskine karşıllk arazi örtüsü içerisinde doğal ve yarı doğal alanlar dikkate alınmıştır. Tüm bu veriler eşit ağırlıklarla çakıştırılarak diğer korunacak alanlar için uygunluk bulunmuştur (Şekil 16).

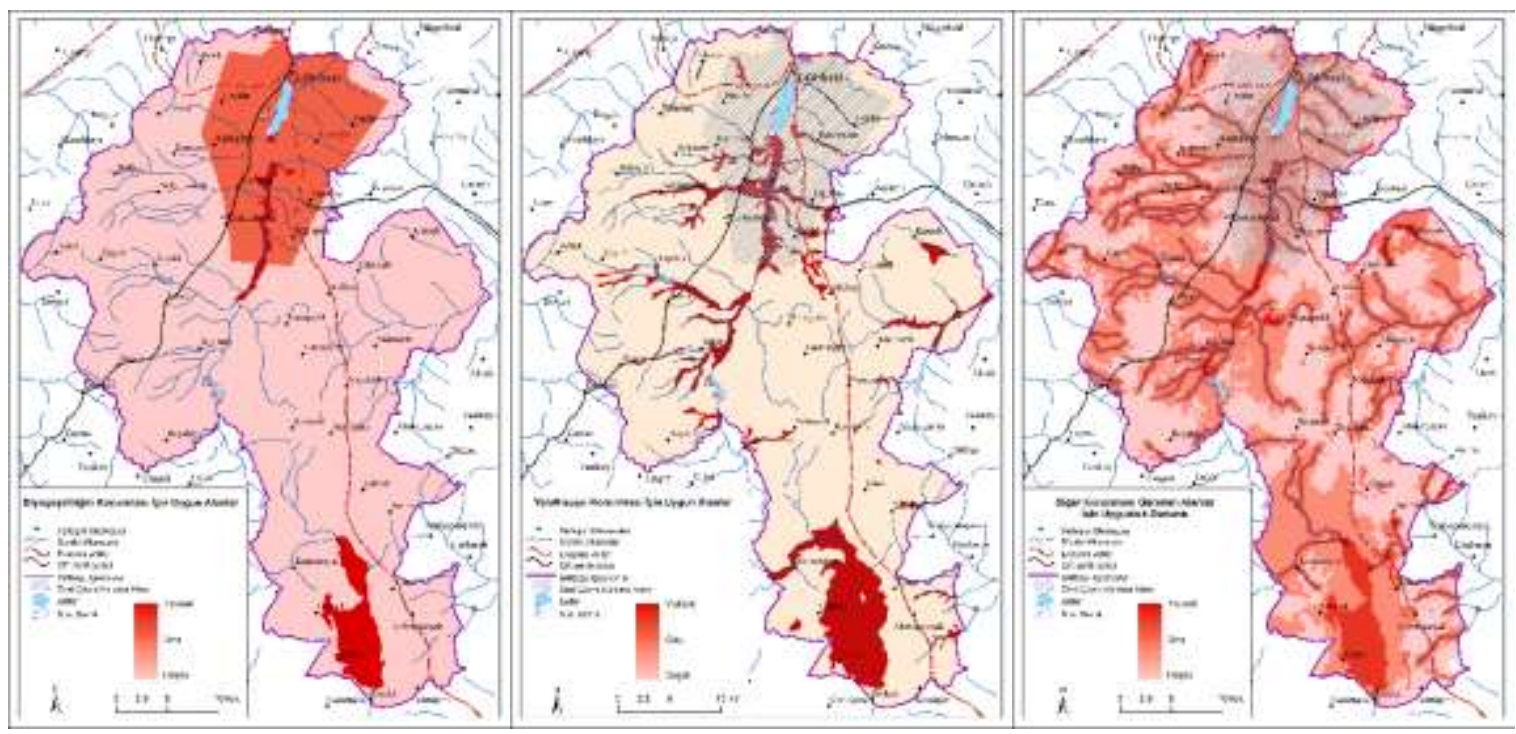

Şekil 14, 15 ve 16. Gölbaşı İlçesinde Biyoçeşitliliğin, Yeraltı Suyunun ve Diğer Alanların Korunması İçin Uygunluk Durumu

Ana amaca yönelik geliştirilen bu üç harita biyolojik çeşitliliğe 0,34 diğerlerine 0,33 ağırlık atanarak çakıştırılmış ve koruma için uygun alanlar belirlenmiştir (Şekil 17).

Gölbaşı ilçesi geneli, koruma alanları bakımından orta ve düşük dereceli uygunluk göstermektedir. Nitekim ilçe yüzölçümünün $\% 58$ 'i orta, $\% 34$ 'ü düşük ve $\% 8$ 'i ise yüksek uygunluğa sahip olarak bulunmuştur. Mahalle bazında değerlendirildiğinde toprakları içerisinde yüksek koruma uygunluğunun bulunduğu sadece 17 mahalle vardır (Çeltek, Gölbek, Akören, Çarsak, Oğulbey, Yağlıpınar, Altınçanak, Emirler, Dikilitaş, Karagedik, Yavrucak, Karşıyaka, Gökçehöyük, Gaziosmanpaşa, Hacımurat, Hacıhasan, Karaaliyazlık). Sınırları içerisinde sadece orta ve yüksek koruma alanı olan mahalle sayısı ise 8'dir (Karşıyaka, Gaziosmanpaşa, Hacıhasan, Örencik, Seğmenler, Bahçelievler, Şafak ve Eymir). 


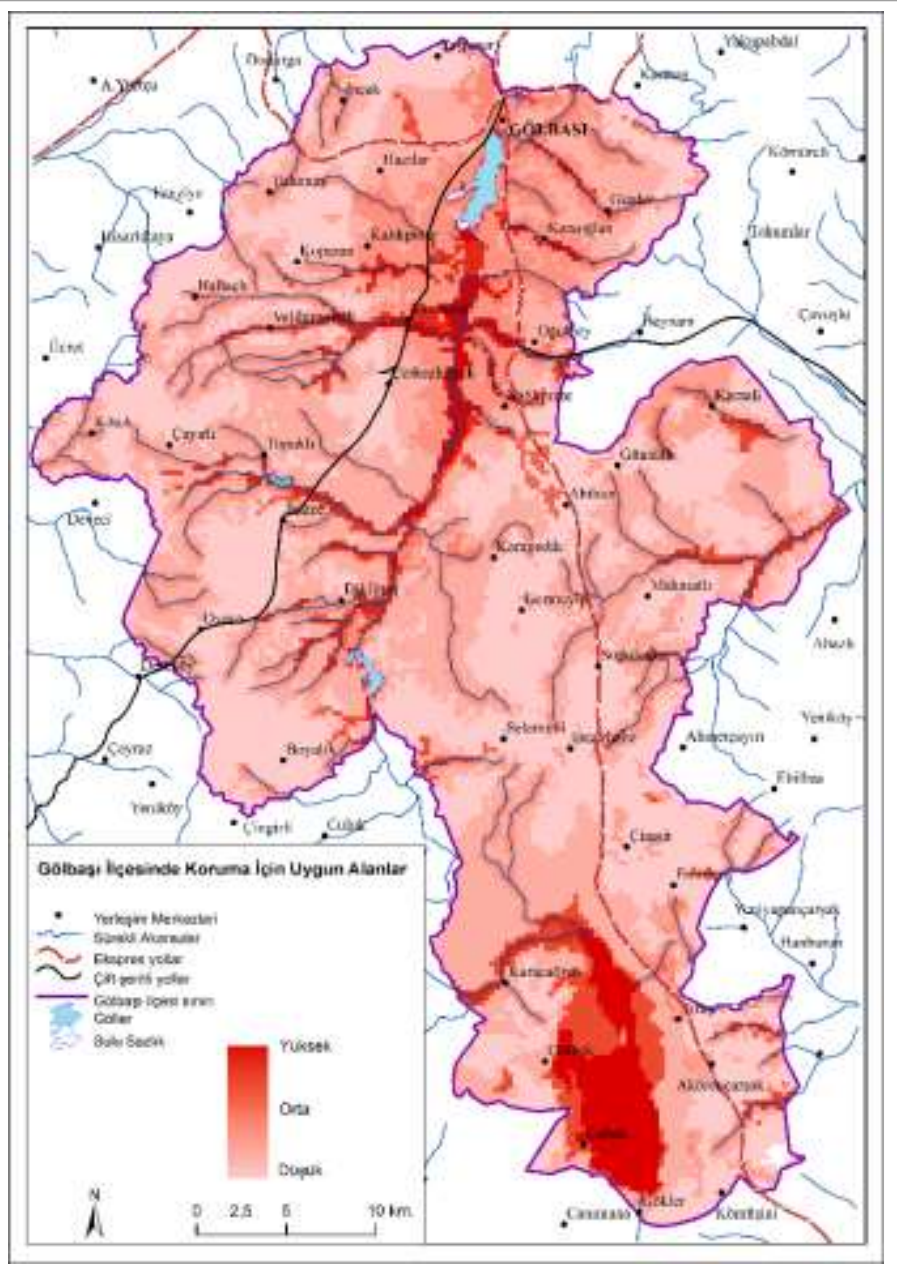

Şekil 17. Gölbaşı İlçesinde Koruma İçin Uygun Alanların Dağılımı

\subsection{Yerleșim Alanları Uygunluğunun Belirlenmesi}

Modelde yerleşim uygunluğu; oturma alanları, iş ve ticaret alanları, perakende ve sanayi alanları olmak üzere dört temel başlık altında ele alınmış her biri için fiziki ve ekonomik uygunluklar belirlenmiş ve bu dört amaca yönelik üretilen uygunluk haritaları çakıştırılarak ana amaca yani yerleşim alanı uygunluğuna ulaşılmıştır. Gölbaşı ilçesinde iş ve ticaret alanı kapsamı dışında perakende alanlarının bulunmaması nedeniyle diğer üç amaca yönelik uygunluklar dikkate alınarak yerleşim alanı uygunluğu belirlenmiştir.

\subsubsection{Oturma alanları uygunluğunun belirlenmesi}

Öncelikle toprak korozyonu ve drenaj özellikleri dikkate alınarak oturma alanları için toprak uygunluğu belirlenmiştir. İyi drene edilmiş ve az korozyona sahip topraklar seçilerek derecelendirilmiştir. Korozyon toprağın yapısı; nemi, havanın toprak içine nüfuzu, toprağın pH'ı, tuz oranı, sıcaklığı ve topraktaki biyolojik aktiviteye göre değişmektedir ve iletkenliği yüksek topraklar çok koroziftir (Çakır, 2016: 38). Gölbaşı ve çevresi için yapılan çalışmalarda alınan toprak örneklerinde, toprağın elektriksel iletkenlik değerleri yüzey örneklerinde 0,015-1,30 mS.cm -1, yüzey altı horizonlarda ise 0,009 - 0,98 mS.cm -1 olarak ölçülmüsstür. Mogan Gölü’nün güneyinde yer alan bataklık alanda ise bu değer; yüzeyde $16,75 \mathrm{mS} . \mathrm{cm}-1$, yüzey altında ise $22,50 \mathrm{mS} . \mathrm{cm}-1$ olarak tespit edilmiştir (Başkan, 2004: 54). Bu nedenle çalışmada, sazlık ve bataklık alanların üzerinde bulunan topraklar korozyonun yüksek olduğu alanlar olarak dikkate alınmıştır. Ancak bu 
konunun ayrıntılı toprak analizleriyle mutlaka haritalanması gerekmektedir. Daha sonra akarsu ve göl alanlarına dikey mesafede 10m'den yüksek olmak eşiği getirilerek taşkın alanları hesaplanmıştır. Mevcut faylara mesafe alınarak deprem riski belirlenmeye çalışılmıştır. Ulaşım ağlarından mesafe hesaplanarak gürültüden uzak bir alan tercih edilmiştir. Hava kalitesi için sanayi alanlarından mesafe dikkate alınmıştır. Ardından toprak 0,20; taşkın 0,35; gürültü 0,25, deprem riski 0,25 ve hava kalitesi 0,05 olarak ağırlıklandırılarak çakıştırılmış ve oturma alanları için fiziki uygunluk durumu belirlenmiştir (Şekil 18).

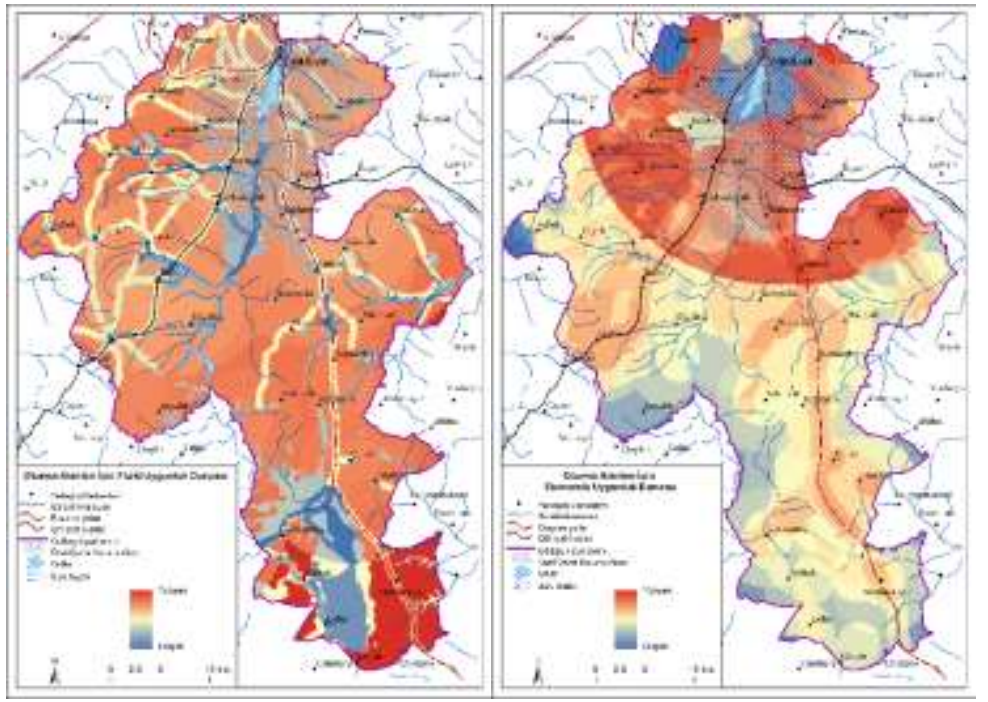

Şekil 18 ve 19. Gölbaşı İlçesinde Oturma Alanları İçin Fiziki ve Ekonomik Uygunluk Durumu

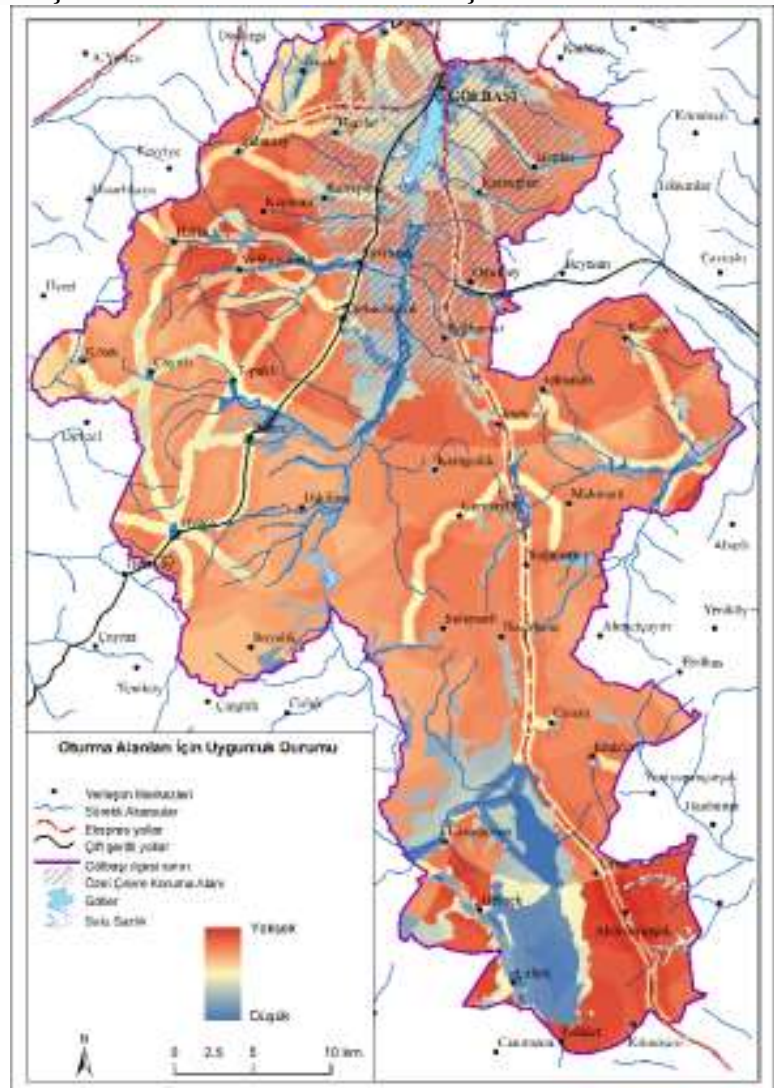

Şekil 20. Gölbaşı İlçesinde Oturma Alanları İçin Uygun Alanların Dağılımı 
Oturma alanları için ekonomik uygunluk kriterleri olarak mevcut oturma alanlarına yakınlık; okul, hastane, ulaşım ağı, park ve rekreasyon alanlarına, tarihi ve kültürel alanlara yakın arazi değeri düşük olan yerler alınmıştır. Mevcut oturma alanlarına mesafe 0,25 ; okullara mesafe 0,15 ; hastanelere mesafe 0,15 ; ulaşım ağına yakınlık 0,15 ; park, rekreasyon ve tarihi alanlara yakınlık 0,05 ; ve arazi bedelleri 0,25 ağırlıklandırılarak çakıştırılmış ve oturma alanları için ekonomik uygunluk bulunmuştur. Ardından oturma alanları için oluşturulan fiziki ve ekonomik uygunluk haritaları eşit ağırlıklarla çakıştırılarak oturma alanları için uygunluk durumu belirlenmiştir (Şekil 19 ve 20).

\subsection{2. İş ve Ticaret Alanları İçin Uygunluğun Belirlenmesi}

Gölbaşı ilçesinde iş ve ticaret alanlarının oturma alanlarıyla iç içe girmesi, bu alanların fiziki uygunluğunun oturma alanları fiziki uygunluğu ile aynı özellikleri taşımasına neden olmuştur (Şekil 21). Burada farklılık ekonomik uygunlukta ortaya çıkmaktadır. İş ve ticaret alanlarında ekonomik uygunluk için; mevcut oturma alanlarına yakınlık, çevredeki kentsel alanlara mesafe, ana yollara yakınlık, park, rekreasyon alanları, tarihi ve kültürel alanlara yakınlık, hizmet alanlarına mesafe, arazi bedelleri, diğer iş ve ticaret alanlarına yakınlık dikkate alınmıştır. Ulaşım ağına mesafe 0,25 ; mevcut iş ve ticaret alanlarına mesafe 0,20 ; oturma alanlarına mesafe 0,15 ; çevredeki kentsel alanlara mesafe 0,15 ; hizmet alanlarına mesafe 0,10 ; arazi bedellerine 0,10 ; park, rekreasyon, tarihi ve kültürel alanlara mesafe 0,05 ağırlıkları atanarak çakıştırılmış, iş ve ticaret alanlarına ekonomik uygunluk belirlenmiştir (Şekil 22). Ardından hem fiziki hem de ekonomik uygunluk haritaları eşit ağırlıklarla çakıştırılarak iş ve ticaret alanları uygunluğu oluşturulmuştur (Şekil 23).

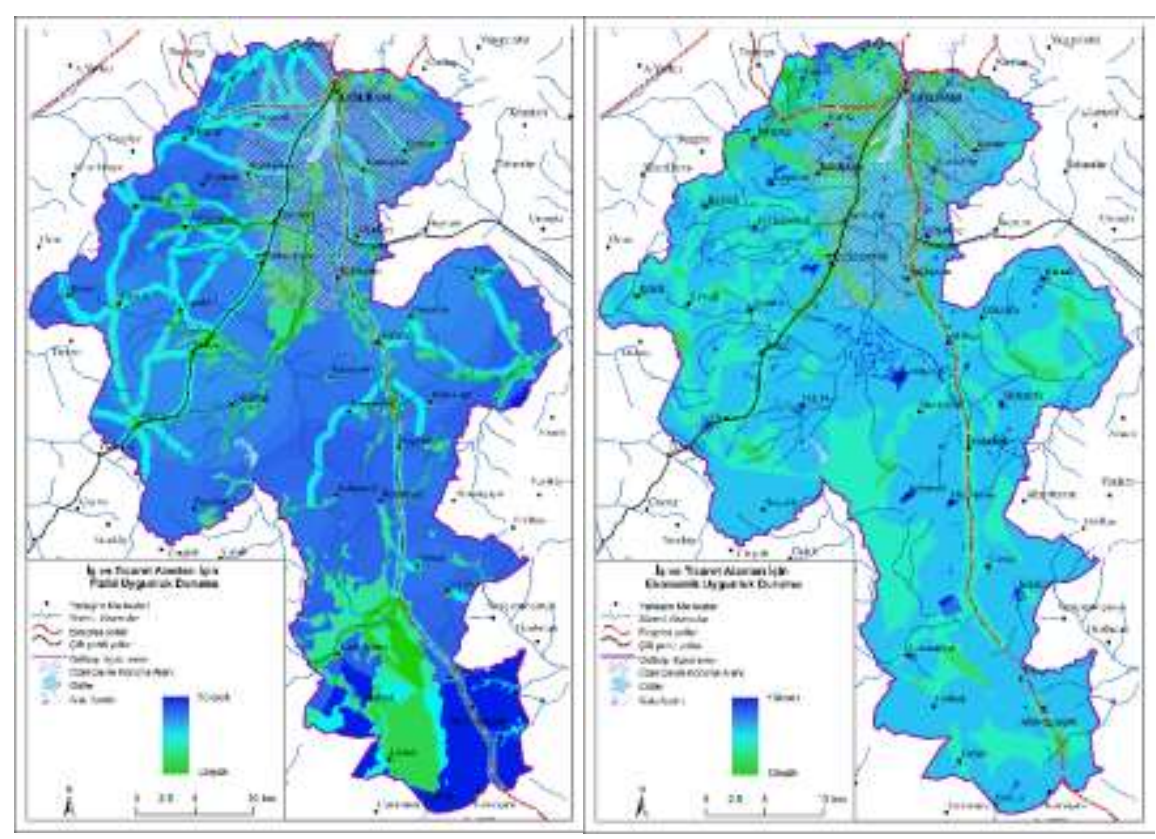

Şekil 21 ve 22. Gölbaşı İlçesinde İş ve Ticaret Alanları İçin Fiziki ve Ekonomik Uygunluk Durumu 


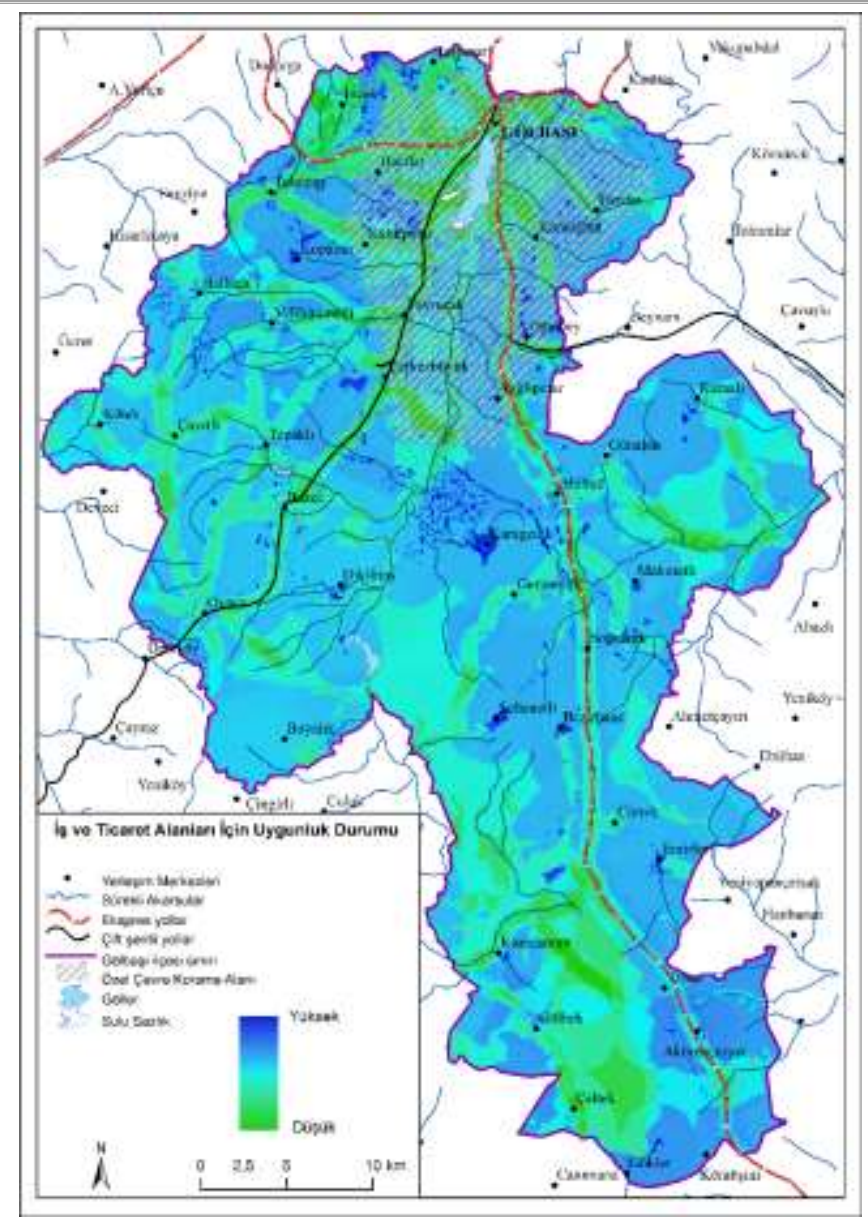

Şekil 23. Gölbaşı İlçesinde Ticaret Alanları İçin Uygun Alanların Dağılımı

\subsubsection{Sanayi Alanları İçin Uygunluğun Belirlenmesi}

Modelde toprağın korozyon ve drenaj özellikleri ile taşkın riski sanayi alanları için fiziki uygunluk olarak belirlenmiş, eşit öneme sahip olarak çakıştırılmış ve sanayi alanları için uygunluk belirlenmiştir (Şekil 24). Sanayi alanlarının ekonomik uygunluğu için; oturma alanlarına uzaklık, mevcut sanayi alanlarına yakınlık, ulaşım ağına yakınlık, hizmet alanlarına yakınlık, arazi bedelleri dikkate alınmıştır. Ulaşım, hizmet ve mevcut sanayi alanlarına yakınlık 0,25; oturma alanlarına mesafe 0,15 ve arazi bedellerine 0,10 ağılık atanarak çakıştırılmış ve sanayi alanları için uygunluk durumu belirlenmiştir (Şekil 25). Fiziki uygunluk ve ekonomik uygunluk çakıştırılarak sanayi alanları uygunluğu tespit edilmiştir (Şekil 26). 


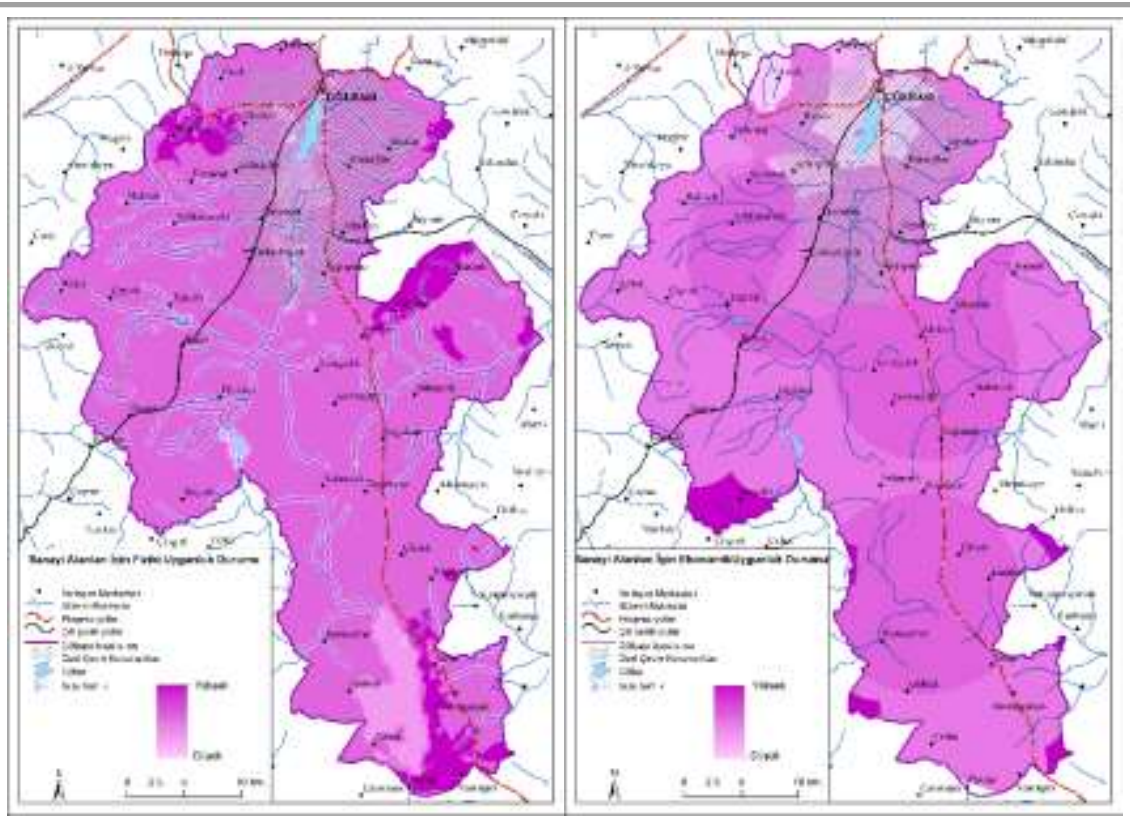

Şekil 24 ve 25. Gölbaşı İlçesinde Sanayi Alanları İçin Fiziki ve Ekonomik Uygunluk Durumu

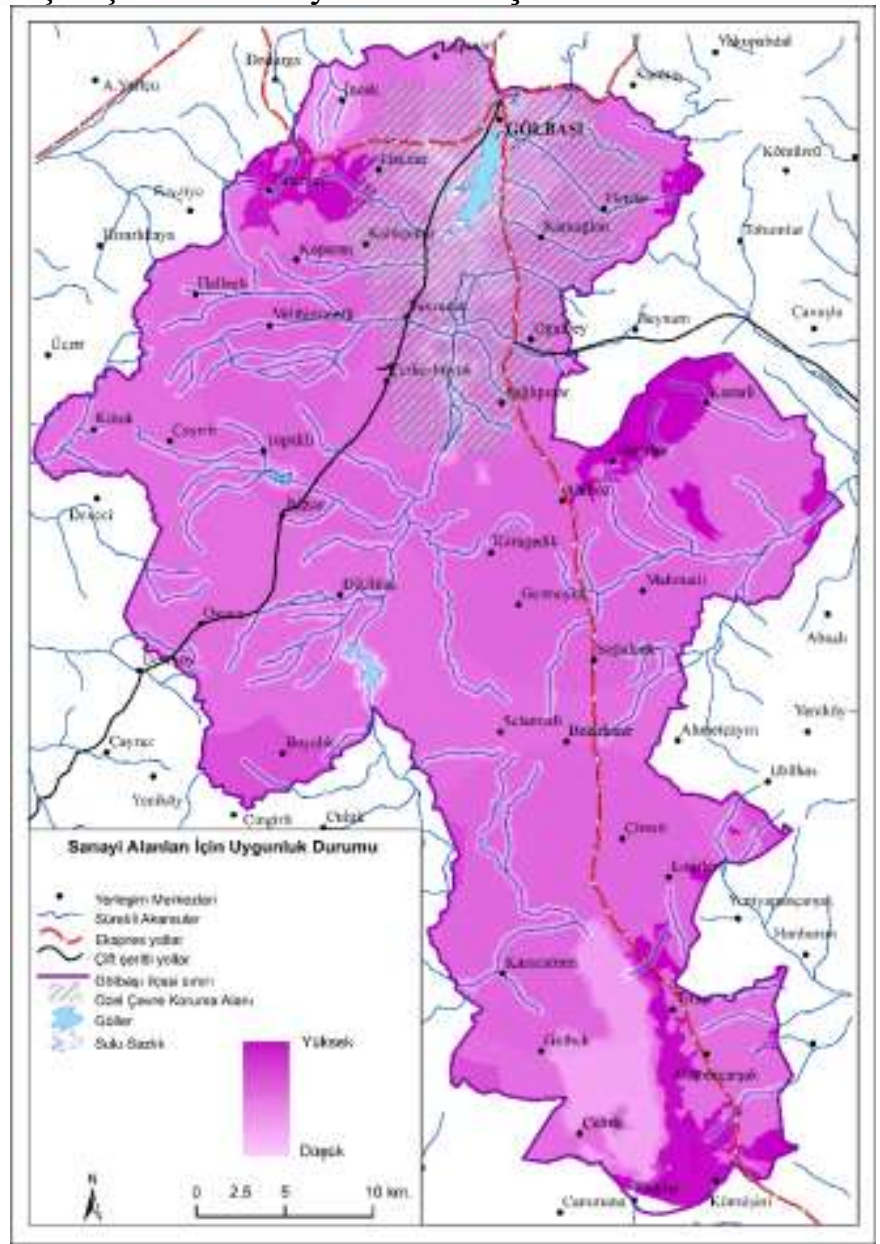

Şekil 26. Gölbaşı İlçesinde Sanayi Alanları İçin Uygun Alanların Dağılımı 
Sanayi alanları açısından ilçe geneli orta uygunluğa sahip hesaplanmıştır. Mevcut durumda da ilçenin güneyinde Konya Yolu boyunca dikkati çeken sanayi alanları, uygunluk analizi sonucunda, kısmen kuzeyde, ilçe sınırlarına yakın alanlarda da yüksek uygunluk göstermiştir.

Oturma alanları, iş ve ticaret alanları ve sanayi alanları için oluşturulan uygunluk haritaları birleştirilerek temel amaçlardan yerleşim alanları uygunluğu elde edilmiştir (Şekil 27).

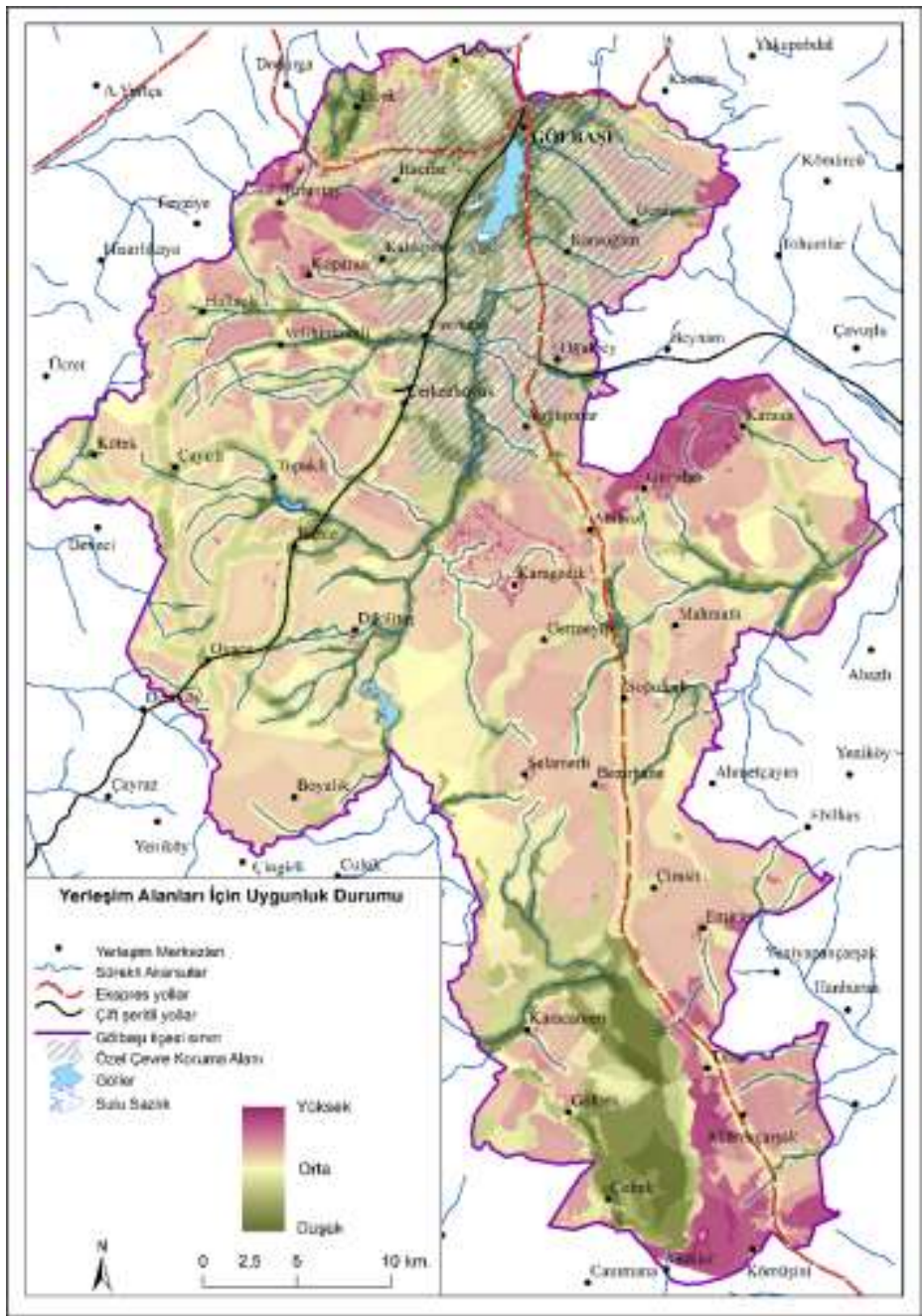

Şekil 27. Gölbaşı İlçesinde Yerleşim Alanları İçin Uygun Alanların Dağılımı

\section{4. Çatışma Alanlarının Belirlenmesi}

Tarımsal uygunluk, koruma alanları uygunluğu ve yerleşim alanlarına uygunluk ana amacına ulaşıldıktan sonra bu üç uygunluk derecesi için normalleştirme ve $1 / 3$ aralık büyüklügünde standart sapmaya göre yeniden sınıflandırma işlemi yapılmıştır. Üç ana kritere göre kodlar atanarak uygunluk durumları düşük, orta ve yüksek olarak belirlenmiş ve tablolaştırılmıştır (Tablo 3). Ardından; "tarımsal uygunluk + koruma uygunluk + yerleşim uygunluk" hesaplamasıyla kodlar birleştirilmiş ve çatışma alanları belirlenmiştir (Şekil 28 ve Tablo 4).

Gölbaşı ilçesinde uygunluk analizlerinde olduğu gibi çatışma alanlarında da orta dereceli çatışmalar hâkimdir (Tablo 4). Bu ikili çatışmalar içerisinde tarımsal alanlar önemli bir yere sahip olmuştur. İkili karşılaştırmalar ve alansal değerler incelendiğinde tarımın yerleşim alanlarıyla olan çatışmasının hâkim olduğu görülmektedir ki, bu durum aslında Ankara şehri çevresindeki kırsal 
alanlar için beklenen bir durumdur (Bayar \& Karabacak, 2020b). İlçe yüzölçümünün yaklaşık \% 66'sında arazi örtüsü çatışmasının görülmesi de bu durumun devam edeceğine işaret etmektedir (Tablo 4).

Tablo 3. Yerleşim, Koruma ve Tarım Alanları Uygunlukları İçin Normalleştirilmiş Hücre Değerleri, Atanan Değerler ve Uygunluk Durumu

\begin{tabular}{|c|c|c|c|}
\hline Ana Amaç & Normalleştirilmiş Hücre Aralıkları & Atanan Değer & Uygunluk \\
\hline \multirow{19}{*}{ Yerleşim } & $0,000000000-0,299191571$ & 1 & Düşük \\
\hline & $0,299191571-0,338580786$ & 1 & Düşük \\
\hline & $0,338580786-0,377970000$ & 1 & Düşük \\
\hline & $0,377970000-0,417359214$ & 1 & Düşük \\
\hline & $0,417359214-0,456748429$ & 1 & Düşük \\
\hline & $0,456748429-0,496137714$ & 1 & Düşük \\
\hline & $0,496137714-0,535526929$ & 1 & Düşük \\
\hline & $0,535526929-0,574916143$ & 1 & Düşük \\
\hline & $0,574916143-0,614305357$ & 1 & Düşük \\
\hline & $0,614305357-0,653694571$ & 1 & Düşük \\
\hline & $0,653694571-0,693083857$ & 2 & Orta \\
\hline & $0,693083857-0,732473071$ & 2 & Orta \\
\hline & $0,732473071-0,771862286$ & 2 & Orta \\
\hline & $0,771862286-0,811251500$ & 2 & Orta \\
\hline & $0,811251500-0,850640714$ & 3 & Yüksek \\
\hline & $0,850640714-0,890030000$ & 3 & Yüksek \\
\hline & $0,890030000-0,929419214$ & 3 & Yüksek \\
\hline & $0,929419214-0,968808429$ & 3 & Yüksek \\
\hline & $0,968808429-1,000000000$ & 3 & Yüksek \\
\hline \multirow{12}{*}{ Koruma } & $0,000000000-0,002577750$ & 10 & Düşük \\
\hline & $0,002577750-0,067799500$ & 10 & Düşük \\
\hline & $0,067799500-0,133021250$ & 20 & Orta \\
\hline & $0,133021250-0,198243000$ & 20 & Orta \\
\hline & $0,198243000-0,263464750$ & 20 & Orta \\
\hline & $0,263464750-0,328686500$ & 20 & Orta \\
\hline & $0,328686500-0,393908250$ & 30 & Yüksek \\
\hline & $0,393908250-0,459130000$ & 30 & Yüksek \\
\hline & $0,459130000-0,524351750$ & 30 & Yüksek \\
\hline & $0,524351750-0,589573500$ & 30 & Yüksek \\
\hline & $0,589573500-0,654795250$ & 30 & Yüksek \\
\hline & $0,654795250-1,000000000$ & 30 & Yüksek \\
\hline \multirow{13}{*}{ Tarım } & $0,000000000-0,013058318$ & 100 & Düşük \\
\hline & $0,013058318-0,071970455$ & 100 & Düşük \\
\hline & $0,071970455-0,130882591$ & 100 & Düşük \\
\hline & $0,130882591-0,189794727$ & 100 & Düşük \\
\hline & $0,189794727-0,248706864$ & 200 & Orta \\
\hline & $0,248706864-0,307619000$ & 200 & Orta \\
\hline & $0,307619000-0,366531136$ & 200 & Orta \\
\hline & $0,366531136-0,425443273$ & 200 & Orta \\
\hline & $0,425443273-0,484355409$ & 200 & Orta \\
\hline & $0,484355409-0,543267545$ & 200 & Orta \\
\hline & $0,543267545-0,602179682$ & 300 & Yüksek \\
\hline & $0,602179682-0,661091818$ & 300 & Yüksek \\
\hline & $0,661091818-0,720003955$ & 300 & Yüksek \\
\hline
\end{tabular}




$\begin{array}{lll}0,720003955-0,778916091 & 300 & \text { Yüksek } \\ 0,778916091-0,837828227 & 300 & \text { Yüksek } \\ 0,837828227-0,896740364 & 300 & \text { Yüksek } \\ 0,896740364-1,000000000 & 300 & \text { Yüksek }\end{array}$

Tablo 4. Çatışma Alanları, Dereceleri ve İlçe Yüzölçümü İçerisindeki Oranları

\begin{tabular}{lccccccc}
\hline KOD & Çatışma Derecesi & Alan $\left(\mathbf{k m}^{\mathbf{2}}\right)$ & Yüzde $(\boldsymbol{\%})$ & \multicolumn{1}{c}{ KOD } & Çatışma Derecesi & Alan $\left(\mathbf{k m}^{\mathbf{2}}\right)$ & Yüzde $(\boldsymbol{\%})$ \\
\hline 111 & Yüksek & 24 & 1,57 & 223 & Orta & 32 & 2,09 \\
112 & Orta & 54 & 3,53 & 231 & Koruma & 67 & 4,38 \\
113 & Orta & 61 & 3,99 & 232 & Orta & 9 & 0,59 \\
121 & Orta & 46 & 3,01 & 233 & Orta & 3 & 0,20 \\
122 & Orta & 46 & 3,01 & 311 & Orta & 7 & 0,46 \\
123 & Yerleşim & 27 & 1,77 & 312 & Tarım & 84 & 5,49 \\
131 & Orta & 14 & 0,92 & 313 & Orta & 176 & 11,50 \\
132 & Koruma & 5 & 0,33 & 321 & Tarım & 17 & 1,11 \\
133 & Orta & 2 & 0,13 & 322 & Orta & 39 & 2,55 \\
211 & Orta & 36 & 2,35 & 323 & Orta & 14 & 0,92 \\
212 & Orta & 269 & 17,59 & 331 & Orta & 17 & 1,11 \\
213 & Tarım & 344 & 22,50 & 332 & Orta & 4 & 0,26 \\
221 & Orta & 46 & 3,01 & 333 & Yüksek & 1 & 0,07 \\
222 & Yüksek & 85 & 5,56 & & & &
\end{tabular}




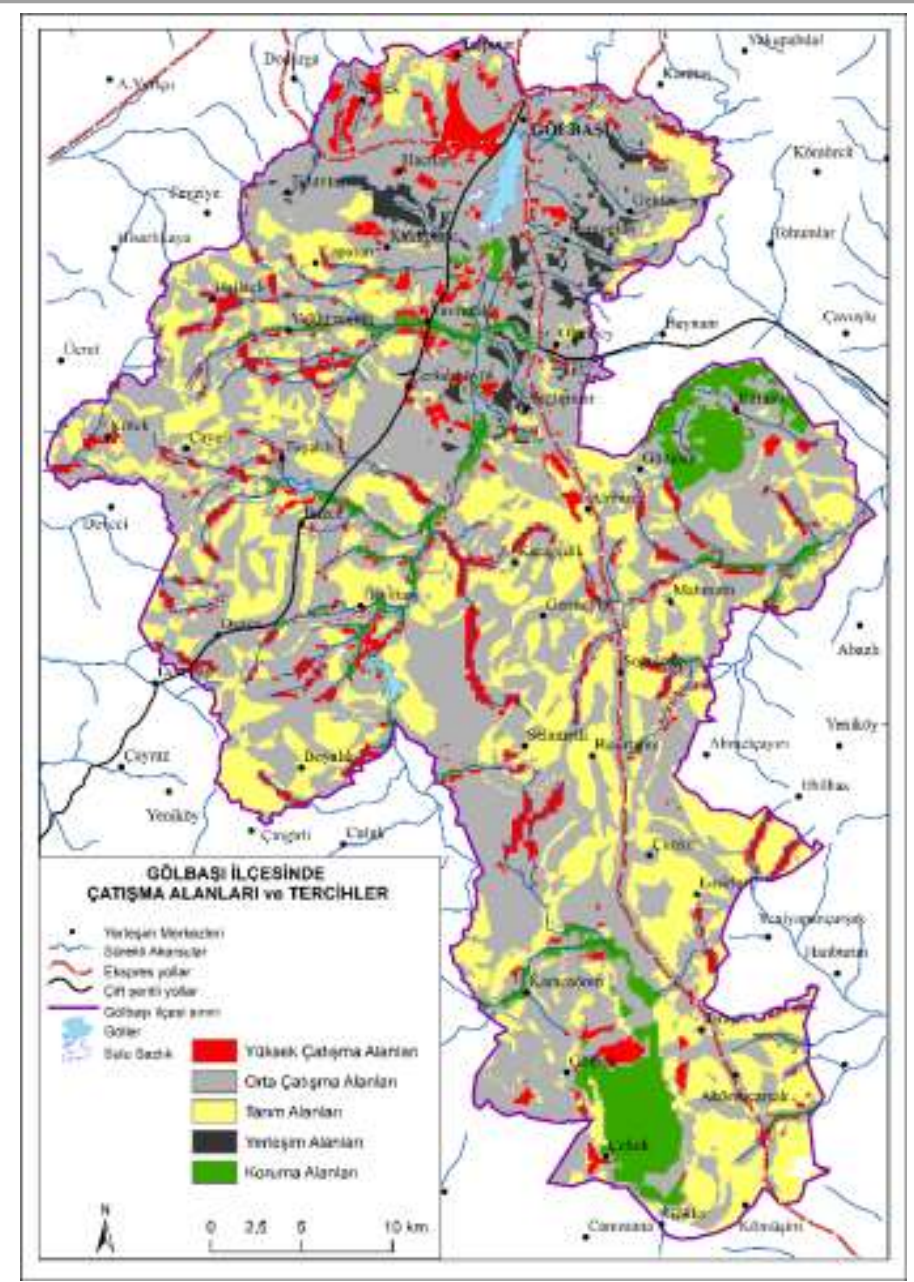

Şekil 28. Gölbaşı İlçesinde Arazi Örtüsü Çatışma Alanlarının Dağılımı

Yöntem kısmında da belirtildiği gibi bir alanda üç arazi örtüsü tipinin de aynı değeri alması yüksek (üçlü) çatışma olduğunu gösterir. Eğer iki rakam aynı değeri alıyorsa orta (ikili) çatışma vardır. Her biri farklı bir değer almış ise çatışma yoktur. İster yüksek isterse orta derecede çatışma alanında olsun rakamların aldıkları değerler çatışmanın boyutunu ve hangi kategorinin baskın olduğunu belirler. Kısacası; 1 düşük, 2 orta ve 3 yüksek olarak değerlendirilir. 111, 222, 333 yüksek çatışma (üçlü) derecesini ifade ederken 111 düşük; 222 orta; 333 yüksek değerde çatıșma olduğunu gösterir.112, 121 (ikili çatışma) çatışan iki değerin de 1 olmasından dolayı düşük değerdedir. Bu bağlamda analiz sonucunda çıkan kodlar aşağıdaki tabloda değerlendirilmiştir (Tablo 5).

Tablo 5. Ana kriterlere Göre Çatışma Değerleri ve Kombinasyonları

\begin{tabular}{llll}
\hline Kod & Çatışma Derecesi & Atama & Çatışma Değeri \\
\hline 111 & Yüksek & Koruma Alanı & Düşük Değerli; Yüksek Çatışma \\
112 & Orta & Yerleşim Alanı & Düşük Değerli; Tarım- Koruma \\
113 & Orta & Yerleşim Alanı & Düşük Değerli; Tarım- Koruma \\
121 & Orta & Koruma Alanı & Düşük Değerli; Tarım - Yerleşim \\
122 & Orta & Koruma Alanı & Orta Değerli; Koruma -Yerleşim \\
123 & Yerleşim Alanı & Yerleşim Alanı & Yok \\
131 & Orta & Koruma Alanı & Düşük Değerli; Tarım-Yerleşim \\
132 & Koruma Alanı & Koruma Alanı & Yok
\end{tabular}




\begin{tabular}{llll}
133 & Orta & Koruma Alanı & Yüksek Değerli; Koruma - Yerleşim \\
211 & Orta & Tarım Alanı & Düşük Değerli; Koruma - Yerleşim \\
212 & Orta & Tarım Alanı & Orta Değerli; Tarım - Yerleşim \\
213 & Yerleşim Alanı & Yerleşim Alanı & Yok \\
221 & Orta & Koruma Alanı & Orta Değerli; Tarım - Koruma \\
222 & Yüksek & Koruma Alanı & Orta Değerli; Yüksek - Çatışma \\
223 & Orta & Yerleşim Alanı & Orta Değerli; Tarım- Koruma \\
231 & Koruma Alanı & Koruma Alanı & Yok \\
232 & Orta & Koruma Alanı & Orta Değerli; Tarım - Yerleşim \\
233 & Orta & Koruma Alanı & Yüksek Değerli; Koruma - Yerleşim \\
311 & Orta & Tarım Alanı & Düşük Değerli; Koruma - Yerleşim \\
312 & Tarım Alanı & Tarım Alanı & Yok \\
313 & Orta & Tarım Alanı & Yüksek Değerli; Tarım - Yerleşim \\
321 & Tarım Alanı & Tarım Alanı & Yok \\
322 & Orta & Tarım Alanı & Orta Değerli; Koruma - Yerleşim \\
323 & Orta & Tarım Alanı & Yüksek Değerli; Tarım - Yerleşim \\
331 & Orta & Koruma Alanı & Yüksek Değerli; Tarım - Koruma \\
332 & Orta & Koruma Alanı & Yüksek Değerli; Tarım - Koruma \\
333 & Yüksek & Koruma Alanı & Yüksek Değerli; Yüksek - Çatışma \\
\hline
\end{tabular}

Gölbaşı ilçesinin \%7,27'si üç; \%58,35'i de iki arazi örtüsü tipi için uygundur. İlçenin \%35,19'unda ise çatışma görülmemektedir. İkili çatışmalar içerisinde tarım alanları ve yerleşim alanları arasındaki çatışmanın olduğu alanlar ilçe yüzölçümünün \% 35,25'inde tarım alanları ve koruma alanları arasındaki çatışma ise \% 13,87'sinde gözlenmiştir. Koruma alanları ve yerleşim alanları arasında çatışma yaşanan alanlar ise çalışma alanının \% 8,43'ünü oluşturmaktadır (Tablo 6).

Tablo 6. Çatışma Kombinasyonlarının Alan ve Yüzdeleri

\begin{tabular}{lcc}
\hline Çatışma Değeri ve Durumu & Alan $\left.\mathbf{( k m}^{\mathbf{2}}\right)$ & Oran $\mathbf{( \% )}$ \\
\hline Düşük Değerli Yüksek Çatışma & 24 & 1,57 \\
Düşük Değerli Koruma A. - Yerleşim A. & 42 & 2,75 \\
Düşük Değerli Tarım A. - Koruma A. & 114 & 7,46 \\
Düşük Değerli Tarım A. - Yerleşim A. & 61 & 3,99 \\
Orta Değerli Yüksek Çatışma & 85 & 5,56 \\
Orta Değerli Koruma A. - Yerleşim A. & 82 & 5,35 \\
Orta Değerli Tarım Koruma & 76 & 4,97 \\
Orta Değerli Tarım A. - Yerleşim A. & 278 & 18,18 \\
Yüksek Değerli Yüksek Çatışma & 2 & 0,13 \\
Yüksek Değerli Koruma A. - Yerleşim A. & 5 & 0,33 \\
Yüksek Değerli Tarım A. - Koruma A. & 22 & 1,44 \\
Yüksek Değerli Tarım A. - Yerleşim A. & 200 & 13,08 \\
Çatışma Olmayan Alanlar & 538 & 35,19 \\
\hline TOPLAM & $\mathbf{1 5 2 9}$ & 100 \\
\hline
\end{tabular}

Çatışma alanlarının tespitinden sonra baskın özelliklere bağlı olarak çatışma kodlarına yeni atamalar yapılmış ve ilçedeki arazi örtüsünün nasıl planlanması gerektiği hesaplanmıştır (Tablo 5; Şekil 29 ve 30). Mevcut arazi örtüsünde olduğu gibi yeni oluşturulan bu arazi örtüsü haritasında da tarımsal alanlar, Gölbaşı ilçesi yüzölçümü içerisinde önemli bir yere sahip olmuştur. Planlamaya göre ilçe yüzölçümünün \%65'i tarımsal alan, \%24'ü koruma alanı ve \%11'i yerleşim alanı olacaktır (Şekil 29 ve 30). 

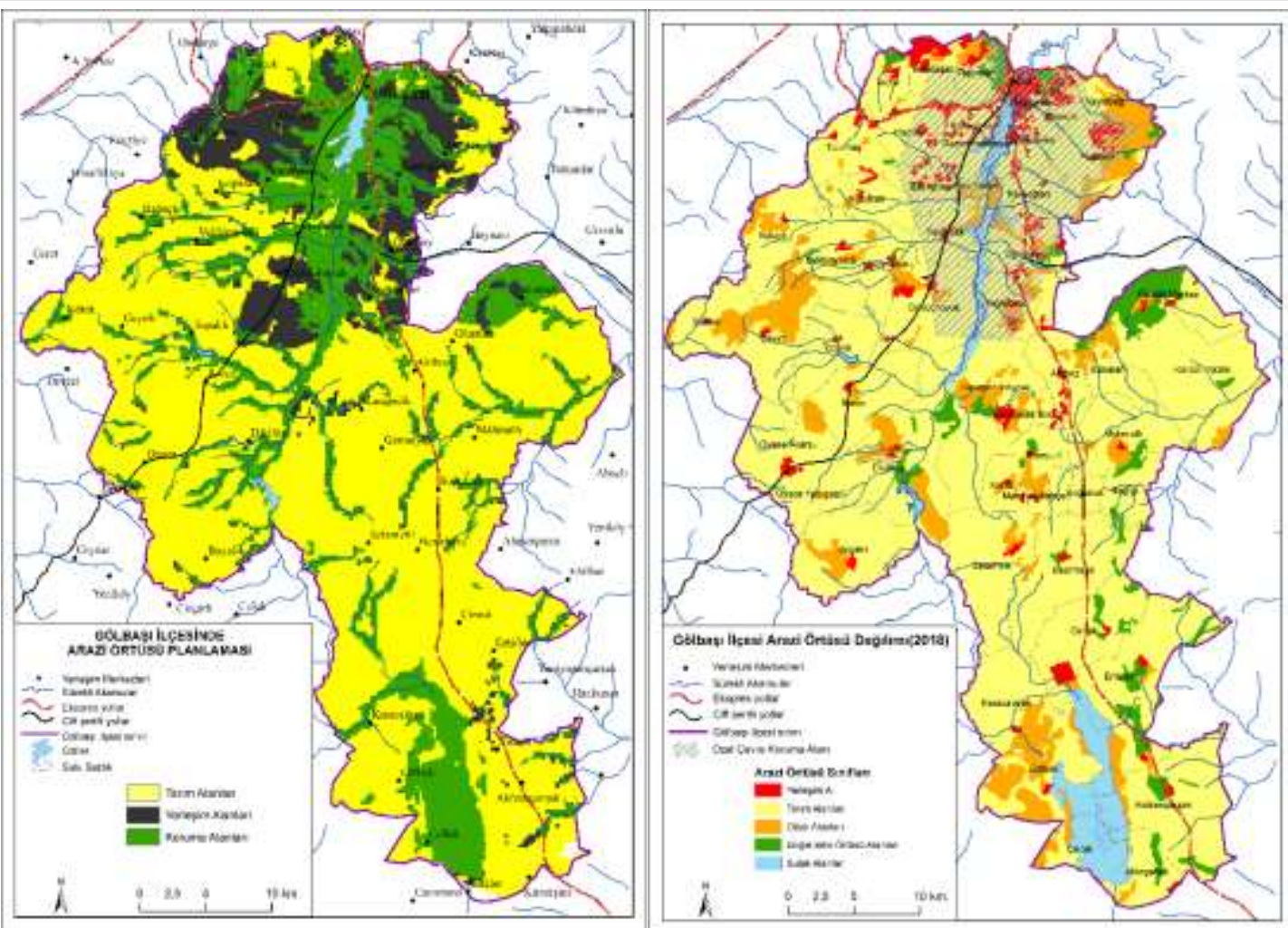

Şekil 29 ve 30. Gölbaşı İlçesinde Çatışma Alanlarına Göre Belirlenen Arazi Örtüsü ve Mevcut Arazi Örtüsü Dağılımı

\section{Sonuç}

Coğrafi Bilgi Sistemleri tabanlı, dinamik bir model olan LUCIS'1 inceleyerek örnek bir uygulama oluşturmayı hedefleyen bu çalışmada arazi örtüsü çatışma alanlarına bağlı olarak Gölbaşı ilçesi için bir planlama yapılmıştır.

İlçede birden fazla arazi örtüsü için uygun olan alanlar daha çok orta derecede çatışma meydana getirmiş ve bu durum daha ziyade tarım ve yerleşim alanları arasında gerçekleşmiştir. Model gereği bu çatışmanın galibi tarım alanları olmuştur. Yüksek çatışma alanları ise kabaca Özel Çevre Koruma Bölgesi güney sınırından kuzeye doğru çizilecek bir hattın kuzeyinde ortaya çıkmıştır. $\mathrm{Bu}$ alandaki hızlı arazi örtüsü değişimi üç temel kategorinin bir arada bulunmasını sağladığı için analizler sonucu tespit edilen yüksek çatışma alanları da burada ortaya çıkmıştır.

İlçedeki genel arazi örtüsü özellikleri dikkate alındığında tarım alanlarının önemli bir yere sahip olduğu görülmektedir (Yüzölçümünün yaklaşık \%77'si). İlçenin Ankara şehriyle temas kurduğu kuzey kesim bir tarafa bırakılırsa çalışma alanında kırsal özellikler hâkimdir. Otlak alanlarının ilçe yüzölçümü içerisinde \%11'lik bir orana sahip olması da bu durumu desteklemektedir. Modele göre üretilen planlama sonucu da Gölbaşı ilçesinde, tarımsal alan hâkimiyetinin devam edeceğini göstermektedir. Son dönemlerde, Gölbaşı Belediyesi tarafından hayata geçirilmeye çalışılan "Kent Çiftliği Projesi" de gerçekleştirilirse ilçedeki tarım alanları korunmuş olacaktır (Gölbaş1 Belediyesi, 2019).

Hazırlanan planlama haritasında yerleşim alanlarının ilçenin kuzey kesiminde artış göstereceği ortaya çıkmıştır. Mevcut durumda da kuzeydoğuda Bahçelievler, Karşıyaka, Seğmenler ve Şafak mahallelerinden oluşan Gölbaşı ilçe merkezi, hızlı büyüyen bir kent yerleşmesidir. Kentin 
kuzeyi Ankara metropolitan alanıyla kontakt halindedir ve bu alanda yer alan kırsal alanlar hızla kentsel hizmet alanlarına dönüşmektedir (Bayar \& Karabacak, 2020a). Kuzeybatıda ise İncek, Taşpınar ve Hacılar uzun zamandan beri Ankara'nın gürültüsünden uzak sakin bir yaşam sürmek isteyenler için bir cazibe alanı olmuştur. Son zamanlarda bazı okul kampüslerinin ve devlet kurumlarının bu alanlara taşınması bu cazibeyi daha da arttırmış, başlangıçta az katlı bahçeli evlerin hâkim olduğu bu alanlarda çok katlı modern siteler inşa edilmeye başlanmıştır. Analizlerden çıkan sonuçlar da bu durumun güçleneceğini göstermiştir.

Çalışma alanı yüzölçümünün \%4'ünü kaplayan sulak alanlar içerisinde Mogan Gölü ve çevresindeki sazlık alanlar önemli bir yere sahiptir. Barındırdığı biyoçeşitlilik nedeniyle ekolojik öneme sahip göl ve çevresi, aynı zamanda Ankara'nın en önemli rekreasyon alanı konumundadır ve 22.10.1990 tarih ve 90/1117 sayılı Bakanlar Kurulu Kararı ile "Gölbaşı Özel Çevre Koruma Bölgesi" olarak ilan edilmiştir (Resmi Gazete, 21.11.1990). 273,94 km² olan bu alan ilçe yüzölçümünün yaklaşık \%18'ine karşılık gelmektedir. Kısmen Özel Çevre Koruma alanı dışında sulak alanların ve doğudaki orman alanın da dâhil edilmesiyle koruma alanlarında az da olsa bir artış beklenmektedir. Genel hatlarıyla değerlendirildiğinde LUCIS model Gölbaşı ilçesi için kabul edilebilir sonuçlar vermiştir.

LUCIS modelin başarısı aslında uygunluk analizleriyle ilişkilidir. Tarım, Koruma ve Yerleşim ana başlıklarıyla sadeleştirilse de model, içerisinde çok fazla uygunluk analizi içermektedir. Coğrafi Bilgi Sistemleri teknolojilerinin gelişmesi bu analizlerin kısa sürede yapılmasına imkân sağlasa da veri çokluğu verinin düzenlenmesinde ve birleştirilmesinde büyük bir dikkat ve sabır gerektirmektedir. $\mathrm{Bu}$ nedenle araştırmacıların yoğun verilerle çalışması yerine olayları temsil edebilecek az sayıda, güvenilir veriyle çalışmaları tavsiye edilir.

Günümüzde veriye erişim giderek kolaylaşmakla birlikte, her kurumun kendi verisini kendi standartlarına göre üretmesi araştırmacılar için verinin düzenlenmesini zorlaştırmaktadır. Aynı alana ait aynı özellikler farklı kurumlar tarafından hazırlanan verilerde farklılık gösterebilmektedir. $\mathrm{Bu}$ nedenle elde edilen verilerin arazi çalışmalarıyla kontrol edilerek düzenlenmesi çok önemlidir. Uygunluk analizleri için toplanan verilerin güvenilir olmayışı veya yanlış kriterlerin dikkate alınması bu modelin başarısını düşürecektir.

Modelin son aşamasında tarım, koruma ve yerleşim alanları atamaları gerçekleştirilirken genel arazi örtüsü değişim eğilimleri de dikkate alınırsa daha doğru sonuçlar üretilebilir. Örneğin; tarım ve yerleşim arasında orta çatışma tespit edilmiş bir alanda modele göre tarım alanı atanacaktır. Oysaki Türkiye'de özellikle büyük kent alanları çeperinde böyle bir çatışmada tarım alanı olarak uygun görünse de kazanan yerleşim alanı olacaktır. Aynı şekilde uygulanan arazi kullanım politikalarının, nüfus özelliklerinin de uygunluk analizleri içerisinde değerlendirilmesi modelin başarısını arttıracaktır.

\section{Kaynakça}

Aburas, M.M., Ho, Y.M., Ramli, M.F. \& Ash'aari, Z.H. (2016). The simulation and prediction of spatio-temporal urban growth trends using cellular automata models: A review. International Journal of Applied Earth Observation and Geoinformation, 52, 380-389. https://doi.org/10.1016/j.jag.2016.07.007

Başkan, O. (2004). Gölbaşı yöresi topraklarının mühendislik-fiziksel özellik ilişkilerinde jeoistatistik uygulaması [Yayımlanmamış doktora tezi]. Ankara Üniversitesi Fen Bilimleri Enstitüsü.

Bayar, R. \& Karabacak, K. (2020a). Başkentin merkezinde köy kalmak: Çankaya ilçesinin (Ankara) kırsal mahalleleri. Ege Coğrafya Dergisi, 29(1), 87-106. 
Bayar, R. \& Karabacak, K. (2020b). Arazi örtüsü üzerindeki beşeri etkinin belirlenmesi: Ankara ili örneği. Journal of Geography, 41, 29-43. http://dx.doi.org/10.26650/JGEOG2019-0043

Canpolat, F.A. \& Dağl1, D. (2021). Türkiye'de arazi kullanım değişimi (1990-2018) ve simülasyonu. M.F. Döker \& E. Akköprü (Ed.), Coğrafya araştırmalarında Coğrafi Bilgi Sistemleri uygulamaları II içinde (s. 87-120). Pegem Akademi.

Carr, M.H. \& Zwick, P.D. (2007). Smart land-use analysis: The LUCIS model. ESRI Press.

Çakır, A.F. ( 2016). Korozyon insanlık için stratejik öneme sahip tabii bir olay. Metalurji Dergisi, $179,35-40$.

Çevre ve Şehircilik Bakanlığı, (2019). Gölbaşı Özel Çevre Koruma Bölgesi yönetim planı 2015 2019. https://webdosya.csb.gov.tr/db/tabiat/editordosya/golbasi_yonetim_plani(1).pdf

De Wrachien, D. (2003). Land use planning: A key to sustainable agriculture. In García-Torres L., Benites J., Martínez-Vilela A., Holgado-Cabrera A. (eds) Conservation agriculture, (pp. 471-483). Springer. http://dx.doi.org/10.1007/978-94-017-1143-2_57

Goodchild, M.F. (2005). GIS and modeling overview. In D.J. Maguire, M. Batty, M.F. Goodchild (Eds.), GIS, spatial analysis, and modeling, (pp. 1-17). ESRI Press.

Gölbaşı Belediyesi, (2019). Gölbaşı kent çiftliği projesi. https://www.ankaragolbasi.bel.tr/haberler/golbasi-na-dev-kent-ciftligi.html

Görmüş, S., Cengiz,S. \& Tağıl,S. (2017). Identification of future land-use conflict and landscape pattern in Denizli, Turkey. International Symposium on GIS Applications in Geography and Geosciences, (pp. 416-426), Çanakkale.

Iojă, I.C., Niţă, M.R., Vânău, G.O., Onose, D.A. \& Gavrilidis, A.A. (2014). Using multi-criteria analysis for the identification of spatial land-use conflicts in the Bucharest Metropolitan Area. Ecological Indicators, 42, 112-121. http://dx.doi.org/10.1016/j.ecolind.2013.09.029

Karabacak, K. (2021). Kentsel alanlarda arazi kullanım modelleri ve uygulamaları. M.F. Döker \& E. Akköprü (Ed.), Coğrafya araştırmalarında Coğrafi Bilgi Sistemleri uygulamaları II içinde (s. 159-184). Pegem Akademi.

Li, X., Yeh \& A.G. (2002). Neural-Network-Based cellular automata for simulating multiple land use changes using GIS. International Journal of Geographical Information Science, 16, $323-$ 343. https://doi.org/10.1080/13658810210137004

McHarg, I. (1969). Design with nature. The Natural History Press.

Mustafa, A., Cools, M., Saadi, I. \& Teller, J. (2017). Coupling agent-based, cellular automata and logistic regression into a hybrid urban expansion model (HUEM). Land Use Policy, 69, 529-540. https://doi.org/10.1016/j.landusepol.2017.10.009

Nayim, N.B. (2011). Bartın peyzajında alan kullanım uyuşmazlıklarının belirlenmesi: LUCIS modeli [Yayımlanmamış doktora tezi]. İstanbul Teknik Üniversitesi Fen Bilimleri Enstitüsü.

Nayim, N.B. (2014). LUCIS Modeli ile konut yerleşimine fiziksel açıdan uygun alanların belirlenmesi, Bartın Kenti örneği. Bartın Orman Fakültesi Dergisi, 16(23-24), 44-58.

Odum, E.P. (1969). The strategy of ecosystem development. Science, 164(3877), 262-270. http://dx.doi.org/10.1126/science.164.3877.262

Openshaw. S. (1998). Neural network, genetic, and fuzzy logic models of spatial interaction. Environment and Planning A, 30, 1857-1872. https://doi.org/10.1068/a301857 
Resmi Gazete (1990). 90/1117 Bakanlar Kurulu Kararı. 21 Kasım 1990 tarih ve 20702 say1l.

Taşdemir, İ. (2017). Düzey II bölgelerinde kalkınma modeli oluşturmada coğrafi bilgi sistemlerinin rolü: LUCIS modeli yaklaşımı [Yayımlanmamış doktora tezi]. İstanbul Teknik Üniversitesi Fen Bilimleri Enstitüsü.

Taşdemir, İ. \& Kaya, Ş. (2015). Yerleşim alanı uygunluk analizi LUCIS model. Türkiye Ulusal Fotogrametri ve Uzaktan Algılama Birliği VIII. Sempozyumu, Konya.

Taşdemir, İ. (2015). LUCIS modeli ile uygun tarım alanlarının belirlenmesi: İstanbul örneği. III. Uluslararası KOP Bölgesel Kalkınma Sempozyumu, Konya.

Zou, L., Liu, Y., Wang, J. \& Yang, Y. (2021). An analysis of land use conflict potentials based on ecological-production-living function in the southeast coastal area of China. Ecological Indicators, 122, 107297. http://dx.doi.org/10.1016/j.ecolind.2020.107297

\section{Beyan ve Açıklamalar (Disclosure Statements)}

1. Araştırmacıların katkı oranı beyanı / Contribution rate statement of researchers: Birinci Yazar/First author \% 50, İkinci Yazar/Second author \% 50.

2. Yazarlar tarafından herhangi bir çıkar çatışması beyan edilmemiş̧ir (No potential conflict of interest was reported by the authors). 